\title{
ANL-78-109
}

ANL-78-109

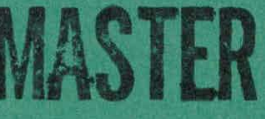

$D R$

2762

\section{THE CURRENT STATUS OF FUSION REACTOR BLANKET THERMODYNAMICS}

by

E. Veleckis, R. M. Yonco, and V. A. Maroni

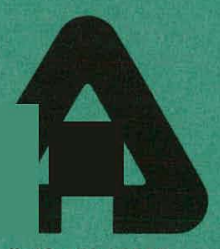

U of C-AUA-USDOE

ARGONNE NATIONAL LABORATORY, ARGONNE, ILLINOIS

Prepared for the U. S. DEPARTMENT OF ENERGY

under Contract W-31-109-Eng-38 


\section{DISCLAIMER}

This report was prepared as an account of work sponsored by an agency of the United States Government. Neither the United States Government nor any agency Thereof, nor any of their employees, makes any warranty, express or implied, or assumes any legal liability or responsibility for the accuracy, completeness, or usefulness of any information, apparatus, product, or process disclosed, or represents that its use would not infringe privately owned rights. Reference herein to any specific commercial product, process, or service by trade name, trademark, manufacturer, or otherwise does not necessarily constitute or imply its endorsement, recommendation, or favoring by the United States Government or any agency thereof. The views and opinions of authors expressed herein do not necessarily state or reflect those of the United States Government or any agency thereof. 


\section{DISCLAIMER}

Portions of this document may be illegible in electronic image products. Images are produced from the best available original document. 
The facilities of Argonne National Laboratory are owned by the United States Government. Under the terms of a contract (W-31-109-Eng-38) among the U.S. Department of Energy, Argonne Universities Association and The University of Chicago, the University employs the staff and operates the Laboratory in accordance with policies and programs formulated, approved and reviewed by the Association.

\section{MEMBERS OF ARGONNE UNIVERSITIES ASSOCIATION}

The Univer sity of Arizona

Carnegie-Mellon University

Case Western Reserve University

The Univer sity of Chicago

University of Cincinnati

Illinois Institute of Technology

University of Illinois

Indiana University

The Univer sity of Iowa

Iowa State University
The University of Kansas Kansas State University Loyola University of Chicago Marquette University The University of Michigan Michigan State University University of Minne sota University of Missouri Northwestern IIniversity University of Notre Dame
The Ohio State University

Ohio University

The Pennsylvania State University

Purdue University

Saint Louis University

Southern Illinois University

The University of Texas at Austin

Washington University

Wayne State University

The University of Wisconsin-Madison

\section{NOTICE}

This report was prepared as an account of work sponsored by the United States Government. Neither the United States nor the United States Department of Energy, nor any of their employees, nor any of their contractors, subcontractors, or their employees, makes any warranty, express or implied, or assumes any legal liability or responsibility for the accuracy, completeness or usefulness of any information, apparatus, product or process disclosed, or represents that its use would not infringe privately-owned rights. Mention of commercial products, their manufacturers, or their suppliers in this publication does not imply or connote approval or disapproval of the product by Argonne National Laboratory or the U. S. Department of Energy.

Printed in the United States of America Available from

National Technical Information Service

U. S. Department of Commerce 5285 Port Royal Road

Springfield, Virginia 22161

Price: Printed Copy $\$ 4.50 ;$ Microfiche $\$ 3.00$ 


\section{ARGONNE NATIONAL LABORATORY \\ 19700 South Cass Avenue \\ Argonne, Illinois 60439}

\section{THE CURRENT STATUS OF FUSION REACTOR BLANKET THERMODYNAMICS}

by

E. Veleckis, R. M: Yonco, and V. A. Maroni

Chemical Engineering Diyision

April 1979

This. repnort was nrepared as an arsount of work sponsored by the United States Govermment. Neither the United States nor the United States Department of Energy, nor any of their employees, nor any of their Energy, nor any of their employees, nor any or their
contractors, tubcontractort, or theis omployeor, maker any warrenty, express or implied, or assumes any legal liability or responsibility for the accuracy, completeness or usefulness of any information, apparatus, product or or usefulness of any information, apparatus, produld not process disclosed, of represents
infringe privately owned rights. 


\section{THIS PAGE \\ WAS INTENTIONALLY \\ LEFT BLANK}


ABSTRACT. . . . . . . . . . . . . . . . . . . . . . . 1

I. INTRODUCTION . . . . . . . . . . . . . . . . . . . 1

II. STATUS REPORT . . . . . . . . . . . . . . . . . 2

A. Liquid Lithium. . . . . . . . . . . . . . . . 3

B. Solid Lithium Alloys. . . . . . . . . . . . . 3

C. Ceramic Materials . . . . . . . . . . . . 3

II I. THERMODYNAMIC STUdIES RELATED TO LIQUID LITHIUM BLANKETS . . . 3

A. The Li-LiH, Li-LiD, and Li-LiT Systems. . . . . . . . . 4

1. Isothermal Studies .. . . . . . . . . . . . 4

2. Solubility Studies ................ . 6

3. Decomposition Pressures in the $(\alpha+\beta)$ Fields. . . 9

4. Species Characterization in the Gas Phase. . . . . . 11

5. Summary of Thermodynamic Data. . . . . . . . . . . 11

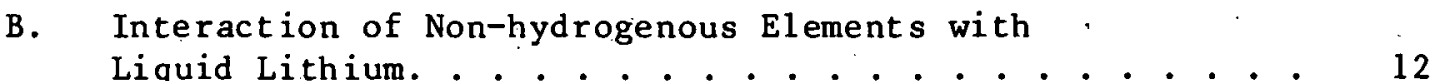

1. The Li-N System. . . . . . . . . . . . . 12

2. The Li-o System. . . . . . . . . . . . . 15

3. The Li-C System. . . . . . . . . . . . . 15

IV. THERMODYNAMIC STUDIES RELATED TO SOLID BLANKETS. . . . . . . . 16

A. Hydrogen Titration Studies. . . . . . . . . . . 16

1. Ihe Li-Al-H System................ . It

2. The Li-Pb-H System .. . . . . . . . . . . . 18

B. Coulometric Titration Studies............. 20

C. Solubility of Hydrogen in Solid Lithium Alloys. . . . . 21

V. STUdiES RELATED to CERAMIC BLANKETS. . . . . . . . . . . . 21

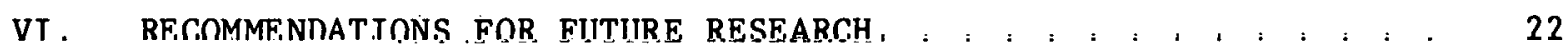

ACKNOWLEDGMENTS . . . . . . . . . . . . . . . . . . . . 23

REFERENCES. . . . . . . . . . . . . . . . . . . . 24 
1. Comparison of the Calculated $P$ vs. N Isotherm with the Literature Data at $700^{\circ} \mathrm{C}$ for the Li-LiD System . . . . . . 6

2. Phase Diagrams for the Li-LiH and Li-LiD Systems Projected on $1000 \mathrm{~K} / \mathrm{T}$ vs. $\log$ (Composition) Plane . . . . . . . 7

3. Plateau-pressure Data for the Li-LiH, Li-LiD, and Li-LiT Systems . . . . . . . . . . . . . . . 10

4. Comparison of Data for the Solubility of $\mathrm{Li}_{3} \mathrm{~N}$ in Liquid Lithiun. . . . . . . . . . . . . . . . . 13

5. Hydrogen Pressure vs. Alloy Composition Isotherms for the Li-Al Syst $\overline{\mathrm{em}}$. . . . . . . . . . . . . . . . . . . .

6. Square Root of Hydrogen Pressure vs. Alloy Composition Isotherms for the Li- $\overline{\mathrm{Pb}}$ System . . . . . . . . . . . 


\section{LIST OF TABLES}

No.

Title

Page

1. Thermodynamic Data for the $\alpha$-Fields of

the Li-LiH, Li-LiD, and Li-LiT Systems . . . . . . . . . . .

2. Miscibility Gap Boundaries of the Li-LiH

and Li-Lid Systems : . . . . . . . . . . . . . . . . .

3. Decomposition Pressures in the $(\alpha+\beta)$ Fields of the Li-LiH, Li-LiD, and Li-LiT systems. . . . . . . . . . .

4. Standard Free Energy of Formation of Solid and Liquid Hydrides. . . . . . . . . . . . . . . . . . . .

5. Maximum Hydrogen Pressures (or Minimum Lithium Activities) at $500^{\circ} \mathrm{C}$ that can be Reached in Solutions of Hydrogen in Selected Intermetallic Compounds Containing Lithium. 
THE CURRENT STATUS OF FUSION REACTOR

BLANKE T THERMODYNAMICS

by

E. Veleckis, R. M. Yonco, and V. A. Maroni

ABSTRACT

The available thermodynamic information is reviewed for three categories of macerials that meet essential criteria for use as breeding blankets in deuterium-tritium (D-T) fueled fusion reactors: liquid lithium, solid lithium alloys, and lithium-containing ceramics. The leading candidate, liquid lithium, which also has potential for use as a coolant, has been studied more extensively than have the solid alloys or ceramics. Recent studies of liquid lithium have concentrated on its sorption characteristics for hydrogen isotopes and its. interaction with common impurity elements. Hydrogen isotope sorption data ( $P-C-T$ relations, activity coefficients, Sieverts' constants, plateau pressures, isotope effects, free energies of formation, phase boundaries etc.) are presented in a tabular form that can be conveniently used to extract the rmodynamic information for the $\alpha$-phase of the Li-LiH, Li-LiD, and $\mathrm{Li}-\mathrm{LiT}$ systems and to construct complete phase diagrams. Recent solubility data for $\mathrm{Li}_{3} \mathrm{~N}, \mathrm{Li}_{2} \mathrm{O}$, and $\mathrm{Li}_{2} \mathrm{C}_{2}$ in liquid lithium are discussed with emphasis on the prospects for removing these species by cold-trapping methods. Current studies on the sorption of hydrogen in solid lithium alloys (e.g., Li-Al and $\mathrm{Li}-\mathrm{Pb}$ ), made using a new technique (the hydrogen titration metliud), have shown that the se alloys should lead to smaller blanket-tritium inventories than are attainable with liquid lithium and that the $\mathrm{P}-\mathrm{C}-\mathrm{T}$ relationships for hydrogen in Li-M alloys $c$ an be estimated from lithium activity data for these alloys. There is essentially no refined thermodynamic information on the prospective ceramic blanket materials. The kinetics of tritium release from these materials is briefly discussed. Research areas are pointed out where additional thermodynamic information is needed for all three material categories.

\section{INTRODUCTION}

of all the potentially useful thermonuclear fuel cycles, the deuteriumtritium reaction,

$$
\mathrm{D}+\mathrm{T}+{ }^{4} \mathrm{He}(3.5 \mathrm{MeV})+\mathrm{n}(14.1 \mathrm{MeV})
$$

remains the leading candidate for near-term fusion reactor applications because of its relatively 1 ow ignition temperature (about $10^{8} \mathrm{~K}$ ) and because most of the thermonuclear energy appears in the form of energetic neutrons which can be converted to thermal energy using the same principles that are 
employed in present-day fission reactors.1 The deuterium required for fueling a D-T reactor is in sufficient natural abundance to last for many hundreds of years. The tritium, however, does not occur naturally in significant quantities and must be produced by some other means. While the prospects for supplying tritium by external manufacture appear to be severely constrained from an economic viewpoint, 2 breeding tritium within the reactor is well recognized as a practically achievable solution. 3 This breeding $c$ an be accomplished via the ${ }^{6} \mathrm{Li}(n, \alpha) \mathrm{T}$ and $7_{\mathrm{Li}}\left(n, n^{\prime} \alpha\right) \mathrm{T}$ nuclear reactions, and in some designs it must be further augmented by the addition of materials with large $(n, 2 n)$ cross sections (e.g., $\mathrm{Be}, \mathrm{Pb}$ ).

The basic features of a D-T fusion reactor consist of a magnetically confined D-T plasma (or an inertially confined D-T pellet) contained in an evacuated chamber. The chamber is surrounded by a blanket material that is interspersed.with some type of coulant/heat-transfor medium. The tritium breeding and neutron thermalization occur in the blanket from which the thermal energy is cariled of $f$ by Llite cuulant in much tho saue way as in a fission reactor.

Although the technology required to effect the utilization of fusion energy must still be considered to be in the very early stages of development, a significant amount of encouraging information has been generated in recent years.1,4,5 The availability of the thermodynamic data to support work in many areas of fusion technology will be pivotal to the development of workable concepts for fusion reactors. We have limited the scope of this paper to recent work on the thermodynamic characteristics of plausible blanket material options for D-T fueled fusion reactors. There are, of course, other areas of fusion technology where thermodynamic considerations are important, e.g., cryogenics, fluid/structure interactions, fuel purification, isotopic enrichment, and surface chemistry. The future expansion of the supportive research base for fusion technology will, no doubt, spur the preparation of separate treatises in these areas.

This review will summarize the pertinent data on three basic classes of prospective blanket materials: liquid lithium, solid lithium alloys, and ceramics. Emphasis will be placed on dilute solutions of hydrogen isotopes and other non-metallic elements in these materials and on the contribution of such data to the development of blanket processing technology.

\section{STATUS REPORT}

In developing generic criteria for the selection of potential breeding materials, the following factors are important: (1) the lithium atom density muot be high enough to yield a positive breeding gain in a reasonable thickness $(<1 \mathrm{~m}$ ) of material; (2) the constituents present wh the lithium must not have parasitic effects on the neutron flux and energy distribution; and (3) the material must be chemically stable in the blanket environment. Other considerations 3 which relate to tritium recovery, hydraulic and mechanical performance of the blanket, availability of resources, and blanket system maintainability are highly concept-dependent and must be weighed against one another in evaluating alternative design choices. 


\section{A. Liquid Lithium}

Liquid lithium is regarded as a leading candidate for the breeding medium. Its major attributes are its high atomic density which results in a favorable tritium breeding gain, low melting point which makes it possible to circulate lithium into and out of the blanket for processing, and excellent heat-transfer characteristics which make it potentially useful as a primary reactor coolant. The drawbacks of liquid lithium stem from its high reactivity with air and water, its corrosivity, and its large magnetohydrodynamic interactions with the confining fields of magnetic fusion reactors. 6

\section{B. Solid Lithium Alloys}

A large number of the fusion reactor design concepts advanced to date have incorporated solid lithium-containing alloys as the breeding material. 3 A number of binary lithium alloy systems are known to have at least one $\mathrm{Li}-\mathrm{rich}$, high-melting compound (e.g., LiAl, Li $7 \mathrm{~Pb}_{2}, \mathrm{Li}_{4} \mathrm{Si}, \mathrm{Li}_{4} \mathrm{Sn}$, and $\mathrm{Li} 3 \mathrm{Bi}$ ) that has the capability of yielding an adequate breeding gain. Cursory thermal hydraulic analyses ${ }^{3}$ have indicated that the nuclear heat generated in appropriately sized pebbles of these alloys can be removed without running into meltdown problems or compromising overall reactor power cycle efficiency. Bench-scale studies 7,8 on selected alloys have shown that, under steady-state tritium production conditions, it is possible to reduce their tritium concentrations to acceptable levels for fusion reactor blankets $[<1$ weight parts per million (wppm) T] by extracting tritium into a stream of helium.

One design study has appeared 9 that employs a liquid Li-Pb alloy (about $38 \mathrm{at} . \% \mathrm{~Pb})$ as the coolant and breeding medium. During the refueling phase of the reactor operating cycle, the alloy is allowed to freeze $\left(\mathrm{fp}=450^{\circ} \mathrm{C}\right.$ ) in the heat exchangers so that the heat of fusion of the alloy can sustain the energy conversion cycle. This design tends to facilitate tritium removal but may create materials compatibility problems that are more severe than those with lithium alone.

\section{Ceramic Materials}

Numerous fusion reactor conceptual designs have employed solid lithiumrontaining ceramics ae the brecding material. 3 With the exception of $\mathrm{Li}_{2} \mathrm{O}$ which has adequate lithium atom density, most of the materials considered have marginal breeding gains and would require utilization of neutron multiplication schemes. Although tritium recovery from the ceramics appears to be straightforward, 7,8,10 the adequacy of their thermal hydraulic performance, their stability in the radiation field, and their compatibility with structural materials at elevated temperatures remains to be demonstrated.

\section{THERMODYNAMIC STUDIES RELATED TO LIQUID LITHIUM BLANKETS}

Of all the candidate blanket materials discussed in the preceding section, liquid lithium has been subjected to the most extensive study from a thermodynamic viewpoint. This section contains a comprehensive review of recent work on the thermodynamics of the systems comprised of lithium with selected non-metallic elements and the implications of the results to fusion reactor technology. 
A. The Li-LiH, Li-LiD, and Li-LiT systems

Until recently, information on the thermodynamics of the systems of lithium with hydrogen isotopes was sparse. Early work on the Li-LiH system was summarized in a 1960 review article by. Messerl1 and in a 1972 book, Lithium Hydride, by Shpilrain and Yakimovich.12 The 1968 book, Metal Hydrides, also contains a chapter on saline hydrides.13 In this section we will discuss the more recent work on the Li-LiH, Li-LiD, and Li-LiT systems that was not covered by the above reviews.

\section{Isothermal Studies}

The measurement of the pressure-composition-temperature ( $\mathrm{P}-\mathrm{C}-\mathrm{T}$ ) relationships under isothermal conditions constitutes perhaps the most widely accepted technique used in investigating the metal-hydrogen systems. The data produced by this technique form a family of $\sqrt{\mathrm{F}} \mathrm{vs}$. C isotherms whose shapes reflect the phase relationships in the system under investigation. In the lithium systems, each isotherm is comprised of two rising portions that are separated by a horizontal plateau.14,15 The composition ranges of the first and second rising portions correspond to homogeneous $\alpha$ - and $\beta$-phases. The constant pressure plateau defines a two-phase $(\alpha+\beta)$ coexistence region.

The isothermal reaction between gaseous hydrogen* and liquid lithium, and the corresponding equilibrium constant $K \mathrm{c}$ an be written as

$$
\begin{gathered}
\mathrm{Li}(\operatorname{soln})+1 / 2 \mathrm{H}_{2}(\mathrm{~g}) \neq \mathrm{LiH}(\operatorname{soln}) \\
\mathrm{K}=\mathrm{N}_{2} \gamma_{2} /\left(\mathrm{N}_{1} \gamma_{1} \sqrt{\mathrm{P}}\right)
\end{gathered}
$$

where the subscripts 1 and 2 refer to $L i$ and LiH, respectively, $N$ is the mole fraction, $\gamma$ is the activity coefficient, $P$ is the equilibrium hydrogen pressure, and the hydrogen is assumed to be dissolved in lithium as a monohydride cpeciee.13 It is customary to express $\gamma$ as a power series in $N$ arcording to Margules' equations, 16 i.e.,

$$
\ln \gamma_{1}=\alpha N_{2}^{2}+B N_{2}^{3}
$$

and

$$
\ln \gamma_{2}=(\alpha+3 / 2 \beta) N_{1}{ }^{2}-B N_{1} 3
$$

Substitution of Eqs. 4 and 5 in Eq. 3 and rearrangement gives a second-order power series in $\mathrm{N}_{2}$

$$
\ln \left(\sqrt{\mathrm{P}} \cdot \mathrm{N}_{1} / \mathrm{N}_{2}\right)=-\ln \mathrm{K}+\alpha\left(1-2 \mathrm{~N}_{2}\right)+1 / 2 B\left(1-3 \mathrm{~N}_{2}{ }^{2}\right)
$$

in which experimentally measured quantities appear on the left-hand side and the unknown, temperature-dependent constants ( $K, \alpha$, and $B$ ) are on the righthand side.

* In order to simplify notation, the hydrogen symbol serves as a stand in for all three hydrogen isotopes. 
Experimental $\sqrt{\mathrm{P}}$ vs. $\mathrm{N}_{2}$ data can be subjected to iterative least-squares procedures to give numerical expressions for the parameters $\ln K, \alpha$, and $\beta$ as linear functions of $1 / T$. These data-fitting procedures have been described in detail elsewhere.14,15 The resulting thermodynamic expressions for the lithium-rich $(\alpha)$ phases of the Li-LiH, and Li-Lid systems are given in Table.1. They are based on work carried out at the Argonne National Laboratory (ANL) $14,15,17$ Sieverts' law constants reported at the Oak Ridge National Laboratory (ORNL)18,19 are also listed in Table 1.

Table 1. Thermodynamic Data for the $\alpha-$ Fields of the Li-LiH, Li-Lid, and Li-LiT Systems

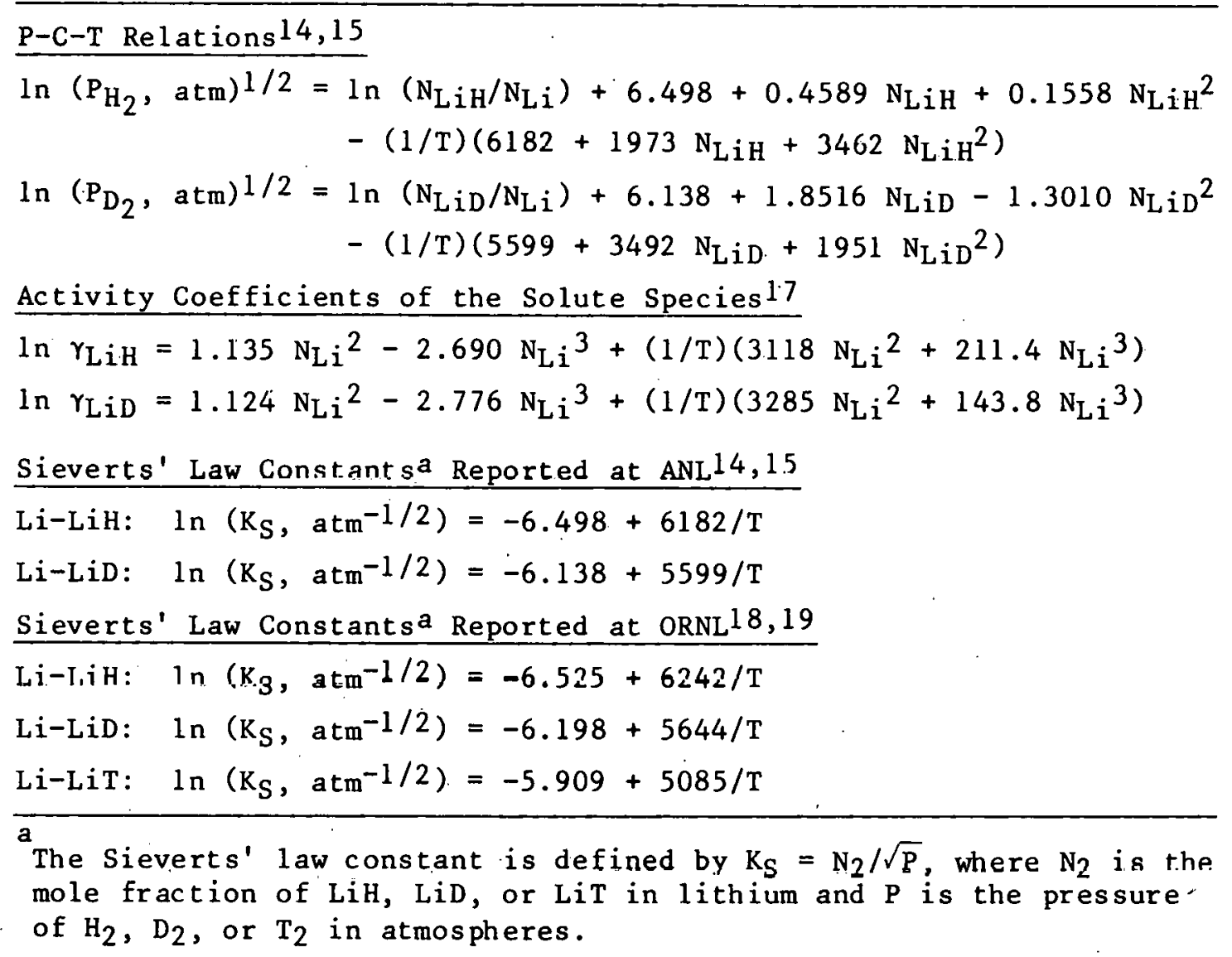

In liquid lithium blankets, hydrogen isotopes are expected to be present at very low concentrations. Thus, for the condition $\mathrm{N}_{2}+0, E q .6$ becomes

$$
\ln \mathrm{K}_{\mathrm{S}}=\ln \mathrm{K}-\alpha-1 / 2 \beta
$$

where $K_{S}=N_{2} / \sqrt{P}$ is the Sieverts' law constant corresponding, in this case, to the change in state $R T$ In $\mathrm{K}_{\mathrm{S}}=\mu_{\mathrm{L} i}^{\circ}(\ell, \mathrm{T}, \mathrm{P})+\mu_{\mathrm{H}_{2}}^{\circ}(\mathrm{g}, \mathrm{T}, 1 \mathrm{~atm})-\mu_{\mathrm{L}}^{\star} \mathrm{H}_{\mathrm{H}}(\mathrm{T}, \mathrm{P})$, where $\mu_{\mathrm{L} i \mathrm{H}}^{*} \mu_{\mathrm{L}}^{\circ}$, and $\mu_{\mathrm{H}_{2}}^{\circ}$ are the standard chemical potentials for the species indicated defined in terms of an infinitely dilute solution, a pure liquid, and a pure ideal gas, respectively. 
The analytical form of the results in Table 1 permits an extrapolation into dilute-solution regions where the data are important for fusion reactor applications. The reliability of such an extrapolation was tested by comparisons with the data that had been obtained experimentally for the Li-LiD system by Smith et al, 18 by Goodall and McCracken,15,20 and by Ihle and Wu.2l The latter two studies were made at very low deuterium concentrations using mass-spectrometric techniques. As shown in Fig. 1 , the agreement among the four studies is very good, thus verifying the accuracy of the equations in Table 1 .

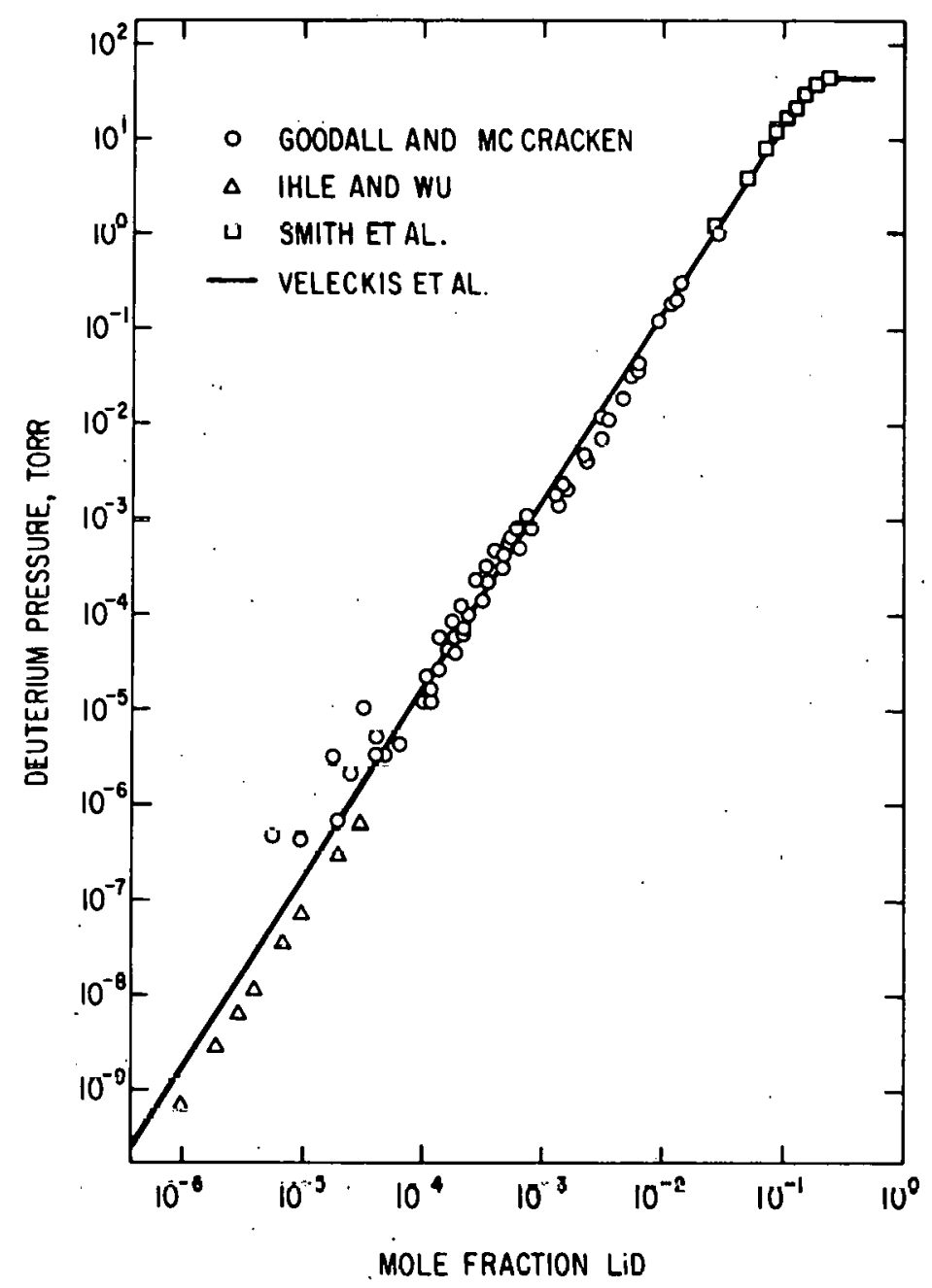

Fig. 1. Comparison of the Calculated P vs. N Isotherm with the Literature Data at $700^{\circ} \mathrm{C}$ for the Li-LiD System.

\section{Solubilicy Studies}

Above the monotectic temperatures the solubility of hydrides in the $\alpha$-phases can be deduced from the points of intersection of the first rising portion and plateau portion of the isotherms. Below the monotectic temperature, where the precipitating phases are solid hydrides, this technique 
is ineffective 14 and more direct experimental methods have been sought. At the University of Nottingham the solubilities of $\mathrm{LiH}^{22}$ and $\mathrm{LiD}^{23}$ in 1 ithium have been determined using a resistometric technique; at ANL the solubility of LiD in lithium was measured by a direct melt-sampling technique. 17 The results of these investigations are shown in Fig. 2 on a plot of $1.000 \mathrm{~K} / \mathrm{T}$ vs.

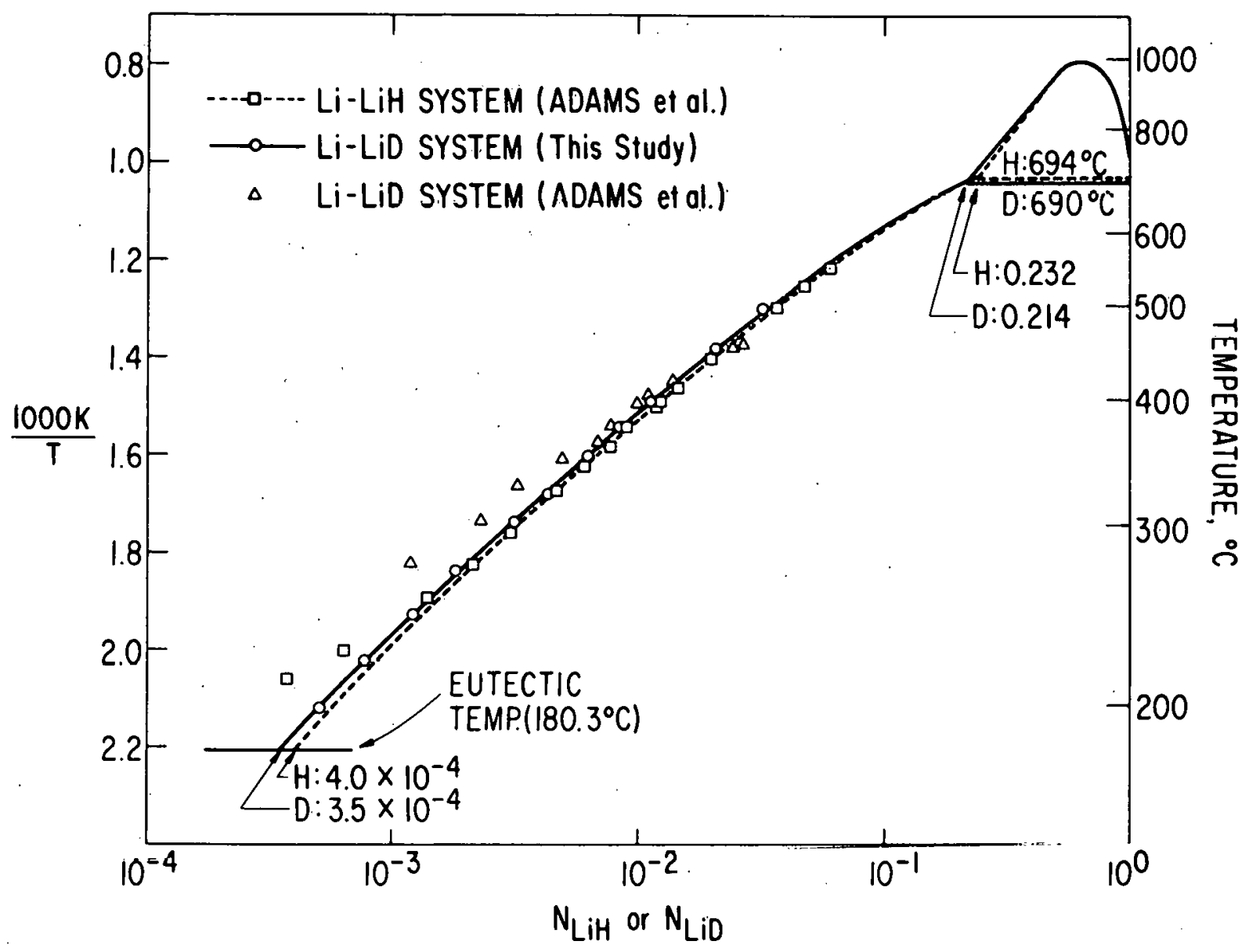

Fig. 2. Phase Diagrams for the Li-LiH and Li-LiD Systems Projected on $100 n \mathrm{~K} / \mathrm{T}$ vs, log (Composition) Plane.

the logarithm of the mole fraction of hydride. In this particular type of plot the data are presented as a conventional phase diagram but with an expanded scale towards low temperatures where the solubility data are more important for fusion reactor applications.

The solubility data in Fig. 2 do not lie on straight lines. Smooth liquidus curves, best.representing the observed data, $c$ an be determined as follows.17 Consider a solution having a composition that corresponds to the liquidus curve at the monotectic temperature. At this point the activity of hydride is near unity and, therefore, the monotectic temperature may be looked upon as the freezing point of the pure hydride (solvent). As 
more lithium (solute) is added, the freezing point of the solution will be lowered as shown by the descending solubility curves in Fig. 2. The activity of saturated solvent, $a_{\mathrm{LiH}}$, may be related to the freezing point lowering by the equation 24

In $a_{\mathrm{LiH}}=\ln \mathrm{\gamma LiH}_{\mathrm{LiH}} \mathrm{N}_{\mathrm{LiH}}$

$$
=\ln a_{\mathrm{LiH}}^{\circ}-\frac{\Delta \mathrm{H}_{\mathrm{m}}}{\mathrm{R}} \frac{\theta}{\mathrm{TT}_{\mathrm{m}}}+\frac{\Delta \mathrm{a}}{\mathrm{R}}\left[\frac{\theta}{\mathrm{T}}+\ln \left(1-\frac{\theta}{\mathrm{T}_{\mathrm{m}}}\right)\right]+\frac{\Delta \mathrm{b}}{\mathrm{R}} \frac{\theta^{2}}{2 \mathrm{~T}}
$$

where $\gamma_{L i H}$ and $\mathrm{N}_{\mathrm{LiH}}$ are the activity coefficient and mole fraction of $\mathrm{LiH}$ at the 1 iquidus line, $\Delta \mathrm{H}_{\mathrm{m}}=5307 \mathrm{cal} / \mathrm{mol}$ is the latent heat of fusion of LiH, $25 \mathrm{~T}_{\mathrm{m}}$ is the monotectic temperature, $\theta=\left(\mathrm{T}_{\mathrm{m}}-\mathrm{T}\right)$ is the freezing point lowering, $\Delta \mathrm{C}_{\mathrm{p}}, \mathrm{cal} /(\mathrm{deg} \cdot \mathrm{mol})=\Delta \mathrm{a}+\Delta \mathrm{bT}=$ $20.61-0.0192 \mathrm{~T}$ is the difference in the heat capacities between liquid and solid $\mathrm{LiH}, 25$ and $\mathrm{a}_{\mathrm{LiH}}$ (about equal to 0.98 ) is the activity of $\mathrm{LiH}$ at the monotectic temperature, serving here as the standard state for liquid LiH. Equation $8 \mathrm{can}$ be taken to be valid also for LiD; assuming identical values for $\Delta \mathrm{C}_{\mathrm{p}}$ and $\Delta \mathrm{H}_{\mathrm{m}}$.

Substitution of equations given in Table 1 for $\gamma_{\mathrm{LiH}}$ and $\mathrm{rLiD}_{\mathrm{L}}$ into Eq. 8 yields expressions for the solubility of LiH and LiD in lithium between the eutectic and monotectic temperatures. These expressions and the miscibility gap boundary data for temperatures above the monotectic are presented in Table 2.

Extrapolation of the liquidus curves to the eutectic temperature yields the eutectic compositions and the freezing point depressions. for Li-LiH and Li-LiD. Since the isotope effects along the liquidus lines are small, approximately the same eutectic composition would apply also to the Li-LiT system. The lowest tritium concentration achievable by direct cold-trapping of lithium would be well in excess of 100 wppm-a level that would be intolerably. high for a fusion reactor blanket system. 
Table 2. Miscibility Gap Boundaries of the Li-LiH and Li-LiD Systems . ${ }^{a}$

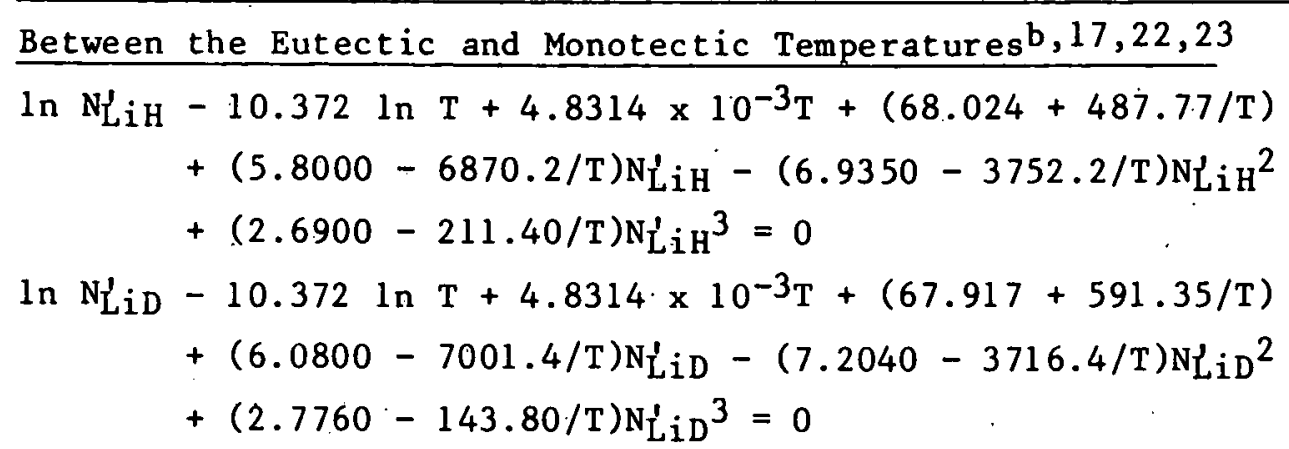

Above the Monotectic Temperature14,15

$$
\begin{aligned}
\text { In } \mathrm{N}_{\mathrm{LiH}}= & 2.235-3576 / \mathrm{T}^{\mathrm{C}} \\
\text { In } \mathrm{N}_{\mathrm{LiD}}^{\prime}= & 2.604-3992 / \mathrm{T}^{\mathrm{C}} \\
\mathrm{N}_{\mathrm{LiH}}^{\prime}= & 0.984\left(\text { at } 710^{\circ} \mathrm{C}\right), 0.971\left(759^{\circ} \mathrm{C}\right), 0.957\left(803^{\circ} \mathrm{C}\right), \\
& 0.923\left(847^{\circ} \mathrm{C}\right), 0.888\left(878^{\circ} \mathrm{C}\right), \text { and } 0.855\left(903^{\circ} \mathrm{C}\right) \\
\mathrm{N}_{\mathrm{Lid}}= & 0.980\left(\text { at } 705^{\circ} \mathrm{C}\right), 0.972\left(756^{\circ} \mathrm{C}\right), 0.953\left(805^{\circ} \mathrm{C}\right), \\
& 0.931\left(840^{\circ} \mathrm{C}\right), \text { and } 0.905\left(871^{\circ} \mathrm{C}\right)
\end{aligned}
$$

${ }^{a}$ The prime and double prime refer to the lithium-rich and hydride-rich limits of the miscibility gap, respectively.

In the temperature range $200-600^{\circ} \mathrm{C}$ these expressions $\mathrm{c}$ an

be approximated by the linear equations: In $\mathrm{N}_{\mathrm{LiH}}=$

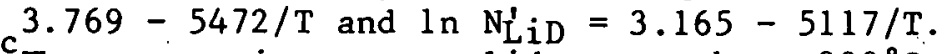

These equations are valid up to about $900^{\circ} \mathrm{C}$.

\section{Decomposition Pressures in the $(\alpha+\beta)$ Fields}

Within the $(\alpha+\beta)$ fields of the Li-LiH phase diagrams, the decomposition pressures do not vary with the composition of the corresponding condensed phases. This property tends to simplify experimental procedures to allow the inclusion of tritium and the determination of precise $H / D / T$ isotope effects.

Several recent studies on the plateau pressures have been reported. For temperatures above the monotectic, measurements have been made by Smith and Land, 26 and by Shpilrain et al .27 using the customary equilibration techniques. Below the monotectic, measurements were made for the $\mathrm{Li}-\mathrm{LiH}$ system by Ihle and Wu, 28 using a combined mass spectrometric-Knudsen effusion t.echnique and by Katsuta et al.,29 using gas chromatography. For temperatures on both sides of the monotectic, plateau pressure studies were made by Smith and Webb30 for the $\mathrm{Li}-\mathrm{LiH}$ and $\mathrm{Li}-\mathrm{LiD}$ systems; at ANL we used an equilibration technique to make comprehensive plateau-pressure measurements for all three hydrogen isotope systems. 31 The results reported in this section are based mainly on this latter study. 
Figure 3 shows the plateau-pressure plots. For a given temperature the pressures are in the order $P_{T_{2}}>P_{D_{2}}>P_{H_{2}}$. Each plot has two distinct linear segments. The point at which the segments intersect defines the monotectic temperature. Linear in $P=A+B / T$ equations derived for each segment are 1 isted in Table 3 . Above the monotectic temperature these equations represent least-squares fits of the data in Fig. 3. Below the monotectic the plateau-pressure data were collectively fitted to individual equations (shown in Table 3 ) in which the parameter $B$ was constrained to a value common to all three systems. These equations yield temperature-independent isotope effects, $\mathrm{P}_{\mathrm{D}_{2}} / \mathrm{P}_{\mathrm{H}_{2}}=1.492$ and $\mathrm{P}_{\mathrm{T}_{2}} / \mathrm{P}_{\mathrm{H}_{2}}=1.751$, that are only slightly different from $\sqrt{2}$ and $\sqrt{3}$ as predicted from the $D / H$ and $T / H$ mass ratios.

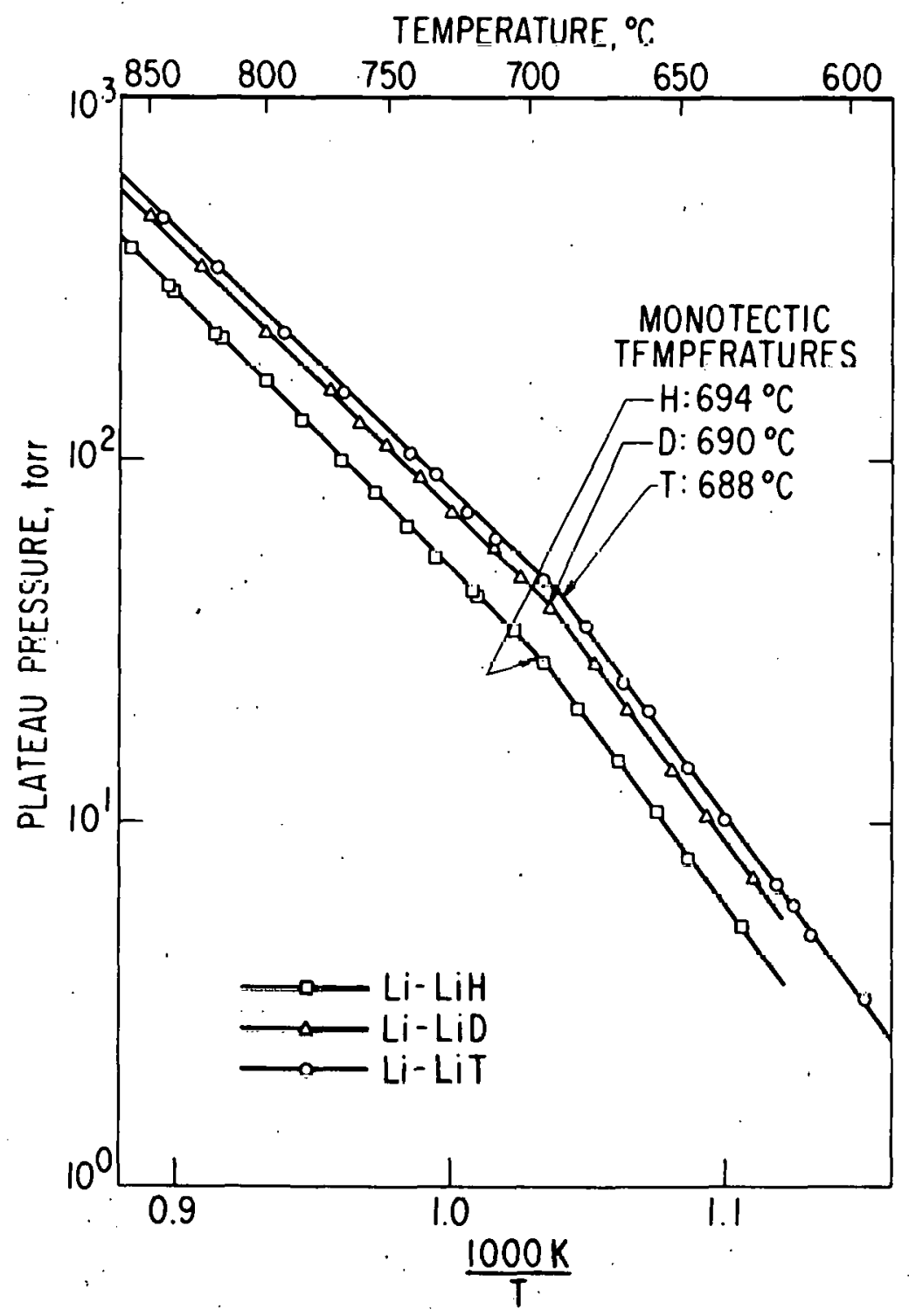

Fig. 3. Plateau-pressure Data for the Li-LiH, Li-LiD, and Li-LiT Systems. 
Table 3. Decomposition Pressures in the $(\alpha+\beta)$

Fields of the Li-LiH, Li-LiD, and Li-LiT Systems. 31

\begin{tabular}{|c|c|c|c|c|}
\hline & \multicolumn{4}{|c|}{$\ln (P$, atm $)=A+B / T$} \\
\hline & \multicolumn{2}{|c|}{ Below Monotectic } & \multirow{2}{*}{$\frac{\text { Above }}{A}$} & Monotectic \\
\hline & A & B & & B \\
\hline Li-LiH & 20.79 & $-23,310$ & 14.71 & $-17,420$ \\
\hline Li-LiD & 21.19 & $-23,310$ & 14.52 & $-16,8 / 0$ \\
\hline Li-LiT & 21.35 & $-23,310$ & 14.29 & $-16,530$ \\
\hline
\end{tabular}

4. Species Characterization in the Gas Phase

In addition to hydrogen molecules, the gas phase over very dilute solutions of hydrogen in lithium is expected to include molecular species containing lithium atoms. The complexity of the gas phase has been recently revealed by Thle and Wu.32 Employing the combined mass spectrometric-Knudsen effusion method, they observed the following molecular species in the gas phase over dilute solutions of deuterium in lithium: $\mathrm{Li}_{2}, \mathrm{Li} 3, \mathrm{LiD}, \mathrm{LiD}_{2}, \mathrm{Li}_{2} \mathrm{D}, \mathrm{Li}_{2} \mathrm{D}_{2}$ and $D_{2}$. From the data they evaluated the partial pressures of each species as functions of liquid-phase composition $\left(10^{-7}<\mathrm{N}_{\mathrm{D}}<10^{-4}\right)$ and temperature $(800$ to $1600 \mathrm{~K})$, their atomization and binding energies, and the equilibrium constants for the exchange reactions among the species.

Although the existence of gaseous hydrides does not affect the Sieverts' law relationships, 32 it leads to an increased density of hydrogen isotopes in the saturated vapuss uver the liquid lithium blanket. Ihle and Wu 33 have pointed out that, owing to this enrichment, it is feasible, in principle, to separate hydrogen isotopes form 1 ithium by fractional distillation performed at temperatures above $1240 \mathrm{~K}$.

\section{Summary of The rmodynamic Data}

The general features of the Li-LiH phase diagrams have been known for many years.11,12 There is a wide monotectic horizontal along which two liquid phases, one rich in lithium $(\alpha)$ the other rich in hydride $(\beta)$, are in equilibrium with essentially stoichiometric LiH. Above the monotectic temperature there is a miscibility gap $[\alpha(l)+\beta(l)]$ that closes at the consolute point. Below the monotectic temperature there is a coexistence region $[\alpha(l)+\operatorname{LiH}(s)]$ that terminates at the eutectic temperature. The data presented in Section III-A permit an accurate construction of the phase diagrams for the Li-LiH and Li-LiD systems and a good approximation for the Li-LiT system, owing to the small effect of isotopic substitution on the phaseboundary compositions. The liquidus lines can be drawn by solving the equations in Table 2. Other phase-boundary data required for phase diagram construction are given in Figs. 2 and 3. 
In addition to phase-boundary information the relations in Tables 1-3 can be used to derive various properties pertaining to the solution thermodynamics of the Li-LiH systems. For example, they have been used to estimate the standard free energies of formation of the liquid 14,15 and solid 31 hydrides (see Table 4 ).

Table 4. Standard Free Energy of Formation of Solid and Liquid Hydrides

Above the Monotectic Temperature $a, 14,15$
$\operatorname{LiH}(\ell): \quad \Delta G_{\mathrm{f}}^{\circ}, \mathrm{kcal} / \mathrm{mol}=13.47 \times 10^{-3} \mathrm{~T}-16.55$
$\operatorname{LiD}(\ell): \quad \Delta G_{\mathrm{f}}^{\circ}, \mathrm{kcal} / \mathrm{mol}=13.17 \times 10^{-3} \mathrm{~T}-15.87$

Below the Monotectic Temperature 31

$$
\begin{array}{ll}
\operatorname{LiH}(\mathrm{s}): & \Delta G_{\mathrm{f}}^{\circ}, \mathrm{kcal} / \mathrm{mol}=19.76 \times 10^{-3} \mathrm{~T}-22.63 \\
\mathrm{LiD}(\mathrm{s}): & \Delta G_{\mathrm{f}}^{\circ}, \mathrm{kcal} / \mathrm{mol}=20.30 \times 10^{-3} \mathrm{~T}-22.73 \\
\mathrm{LiT}(\mathrm{s}): & \Delta G_{\mathrm{f}}^{\circ}, \mathrm{kcal} / \mathrm{mol}=20.64 \times 10^{-3} \mathrm{~T}-22.82
\end{array}
$$

${ }^{a}$ Smith et al. $18 \mathrm{~b}$ have recently reported the following expressions for liquid hydrides:

$\mathrm{LiH}(\ell): \Delta \mathrm{G}_{\mathrm{f}}^{\circ}, \mathrm{kcal} / \mathrm{mol}=12.83 \times 10^{-3} \mathrm{~T}-15.71$

$\operatorname{LiD}(\ell): \quad \Delta G_{f}^{\circ}, \mathrm{kcal} / \mathrm{mol}=11.86 \times 10^{-3} \mathrm{~T}-14.18$

$\operatorname{LiT}(\ell): \quad \Delta G_{\mathrm{f}}^{\mathrm{o}}, \mathrm{kcal} / \mathrm{mol}=10.94 \times 10^{-3} \mathrm{~T}-12.72$

\section{B. Interaction of Non-hydrogenous Elements with Liquid Lithium}

'lhe binary systems of lithium with non-metals other than hydrugen isutopes are ot interest to the tusion program primarily from the standpoint of materials compatibility. These systems have been reviewed by Messer, 34 by Cairns et al., 35 by Adams et al.,36 and by Smith and Moser.37 Because of the limited scope of this presentation, we will concentrate on published work related to the systems $\mathrm{Li}-\mathrm{N}, \mathrm{Li}-\mathrm{O}$, and $\mathrm{Li}-\mathrm{C}$ which has appeared since the earlier reviews.

\section{The ti. -N System}

Nitrogen gas reacts with 1 ithium to form $\mathrm{Li}_{3} \mathrm{~N}$ which exists in liquid lithium solutions probably as an ionic species since the phase in equilibrium with the saturated solutions is solid $\mathrm{Li}_{3} \mathrm{~N}$ and since ammonia is evolved upon hydrolysis of these solutions.

The system $\mathrm{Li}-\mathrm{Li}_{3} \mathrm{~N}$ was first investigated by Bolshakov et al. 38 who employed thermal analysis techniques to determine the liquidus 1 ine between the eutectic temperature and the melting point of $\mathrm{Li}_{3} \mathrm{~N}$. Adams et al ${ }^{22}$ determined the solubility of $\mathrm{Li}_{3} \mathrm{~N}$ in lithium from 200 to $450^{\circ} \mathrm{C}$ using a resistometric techique in which the saturation concentrations are detected by corresponding breaks in the resistivity curves. Yonco et al. 39 determined the solubility of $\mathrm{Li}_{3} \mathrm{~N}$ in lithium from 195 to $441^{\circ} \mathrm{C}$ by taking filtered samples of 
saturated solutions and assaying them for nitrogen using the micro-Kjeldahl method. They also measured the equilibrium nitrogen pressure over solid $\mathrm{Li}_{3} \mathrm{~N}$ between 660 and $778^{\circ} \mathrm{C}$ and the melting point of $\operatorname{Li}_{3} \mathrm{~N}\left(813 \pm 1^{\circ} \mathrm{C}\right)$.

Figure 4 shows a plot of $\ln \left(\operatorname{mol} \% \mathrm{Li}_{3} \mathrm{~N}\right)$ vs. $1 / \mathrm{T}$ constructed from the composite results of these three studies. Below $450^{\circ} \mathrm{C}$ the combined data of the latter two studies were statistically fitted to the 1 inear equation

$$
\ln \mathrm{N}_{\mathrm{Li}_{3} \mathrm{~N}}=3.086-4878 / \mathrm{T}
$$

with $4 \%$ uncertainty in the mean value of $\mathrm{N}_{\mathrm{Li}_{3} \mathrm{~N}}$, the mole fraction of $\mathrm{Li}_{3} \mathrm{~N}$ in lithium. Above $450^{\circ} \mathrm{C}$ the solubility $\mathrm{c}$ an be represented by the curve that is formed by extrapolation of Eq. 9 to a point where the line joins smoothly with the data of Bolshakov et al., although the exact shape of the curve at the melting point of $\mathrm{Li}_{3} \mathrm{~N}$ is subject to question. 39

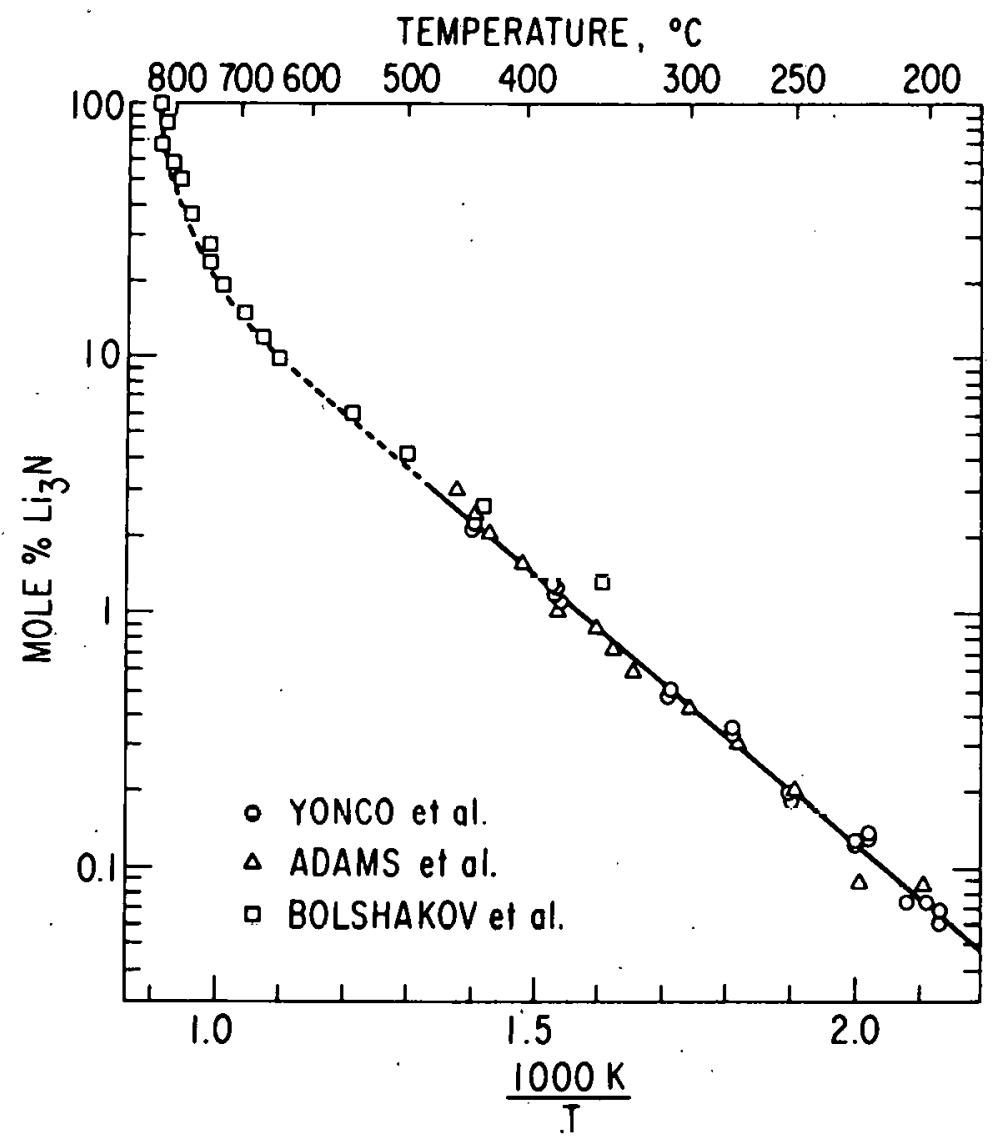

Fig. 4. Comparison of Data for the Solubility of $\mathrm{Li}_{3} \mathrm{~N}$ in Liquid Lithium. 
A eutectic point of 0.047 mol $\% \mathrm{Li}_{3} \mathrm{~N}\left(940\right.$ wppm $\mathrm{N}$ ) and $180.2^{\circ} \mathrm{C}$, inferred from Eq. 9 and from the freezing point depression of 1 ithium, is in good agreement with the values of $0.068 \mathrm{~mol} \% \mathrm{Li}_{3} \mathrm{~N}$ and $180.24^{\circ} \mathrm{C}$ reported by Hubberstey et al. 40 who determined the hypoeutectic liquidus by thermal analysis. The high eutectic concentration precludes cold-trapping as an effective way to remove nitrogen from 1 ithium.

The solubility information in Fig. 4, when used in conjunction with the $\mathrm{Li}_{3} \mathrm{~N}$ decomposition pressures, 39 permits the evaluation of the thermodynamic properties of the $\mathrm{Li}-\mathrm{Li}_{3} \mathrm{~N}$ system. The equilibrium reaction between gaseous nitrogen and liquid lithium to form a liquid solution of $\mathrm{Li}_{3} \mathrm{~N}$ in lithium and the corresponding equilibrium constant $\mathrm{K}$ may be written as

$$
\begin{gathered}
1 / 2 \mathrm{~N}_{2}(g)+3 \mathrm{Li}(\operatorname{soln}) \neq \mathrm{Li}_{3} \mathrm{~N}(\operatorname{soln}) \\
\mathrm{K}=\mathrm{N}_{2} \gamma_{2} /\left(\mathrm{N}_{1}{ }^{3} \gamma_{1} 3 \sqrt{\mathrm{P}}\right)
\end{gathered}
$$

where $N_{1}$ and $N_{2}$ are the mole fractions of $\mathrm{Li}$ and $\mathrm{Li}_{3} \mathrm{~N}, \gamma_{1}$ and $\gamma_{2}$ are their activity coefficients, $P$ is the nitrogen pressure, and the standard states of $\mathrm{Li}$ and $\mathrm{Li}_{3} \mathrm{~N}$ are the pure liquid phases. A reasonable estimate of the $r^{\prime} s c$ an be made from the Margules'
equations 16 truncated at the quadratic term. For the solvent lithium this would give

$$
\ln \gamma_{1}=(\omega / R T) N_{2}^{2}
$$

where $\omega$ is a temperature-independent constant. By application of the GibbsDuhem relationship to Eq. 12 one obtains for the activity coefficient of the sulule $\mathrm{Li} \cdot 3 \mathrm{~N}$

$$
\ln \gamma_{2}=(\omega / R T)\left(N_{1}^{2}-N_{1}^{\prime}\right)-\ln N_{2}^{\prime}
$$

where the primed symbols refer to the values at the liquidus boundary. The constant $\omega$ was evaluated 39 by substituting Eq. 12 into Eq. 11 , selecting values of $P$ and $\mathrm{N}_{2}$ existing at the liquidus boundary, defining solid $\mathrm{Li}_{3} \mathrm{~N}$ as the standard state (i.e., $N_{2}^{\prime} \gamma_{2}^{\prime}=1$ ), and choosing a value for $w$ such that a plot of $1 n$ K vs. $1 / T$ would give a statistically best straight 1 ine. The resulting linear relationship at $\omega=3.14 \mathrm{kcal} / \mathrm{mol}$ ) for $1 \mathrm{n} \mathrm{K}$ vs. $1 / \mathrm{T}$ yielded the following standard free energy of formation of solid $\mathrm{Li}_{3} \mathrm{~N}$

$$
\Delta G_{f}^{\circ}, \mathrm{kcal} / \mathrm{mol}=33.2 \times 10^{-3} \mathrm{I}-39.1
$$

In the temperature range from 600 to $1000 \mathrm{~K}, \Delta \mathrm{G}_{\mathrm{f}}^{\circ}$ values calculated from Eq. 14 are 1.5 to $2.1 \mathrm{kcal} / \mathrm{mol}$ less negative than those 1 isted in the JANAF tables for solid $\mathrm{Li}_{3 \mathrm{~N}}, 41$ based on the recent calorimetric work of 0 'Hare and Johnsion 42 and of Osborne and Flotow. 43 The discrepancy can be considered to be small when one takes into account the approximations made by Yonco et al .39 in deriving the expression for $\Delta G_{f}^{\circ}$. The coefficients in Eq. 14 also compare favorably with those reported in the recent emf studies by Bonomi et al .44 namely, $\Delta G_{\mathrm{f}}^{\circ}, \mathrm{kcal} \mathrm{mol}-1=35.2 \times 10^{-3} \mathrm{~T}-40.65$. 
Dilute solutions of $\mathrm{Li}_{3} \mathrm{~N}$ in lithium are important in the use of

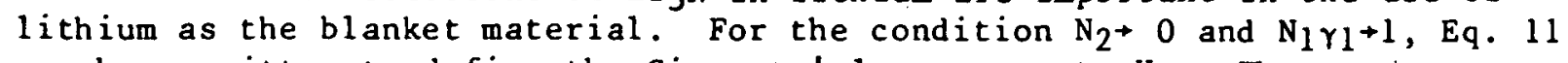
may be rewritten to define the Sieverts', law constant, $\mathrm{K}_{\mathrm{S}}$. Thus,

$$
\lim _{N_{2} \rightarrow 0} N_{2} / \sqrt{P}=K_{S}=K / r_{2}^{*}
$$

where $\gamma_{2}^{*}$ is the activity coefficient of Li $3 \mathrm{~N}$ at infinite dilution, calculated by applying the condition $\mathrm{N}_{1} \rightarrow 1$ to $\mathrm{Eq}$. 13 . For the temperature range $661-778^{\circ} \mathrm{C}$, the Sieverts' law constant can be represented by

$$
\ln \left(\mathrm{K}_{\mathrm{S}}, \mathrm{atm}^{-1 / 2}\right)=-13.80-14,590 / \mathrm{T}
$$

\section{The Li-O System}

The compounds $\mathrm{Li}_{2} \mathrm{O}$ and $\mathrm{Li}_{2} \mathrm{O}_{2}$ are known to exist in the lithiumoxygen system, although only the normal oxide is formed by the direct reaction of oxygen with lithium. ${ }^{34}$ Available thermochemical information for $\mathrm{Li}_{2} \mathrm{O}$ and $\mathrm{Li}_{2} \mathrm{O}_{2}$ has been reviewed elsewhere. 37 Yonco et al. 45 determined the solubility of $\mathrm{Li}_{2} \mathrm{O}$ in lithium for temperatures between 195 and $734^{\circ} \mathrm{C}$ by taking equilibrated melt samples filtered through $2-\mu \mathrm{m}$-pore-size filters. The samples were assayed for oxygen by a fast neutron activation method. The data can be represented by

$$
\ln \mathrm{N}_{\mathrm{Li}_{2} \mathrm{O}}=1.449-6669 / \mathrm{T}
$$

with a correlation coefficient of 0.997 , where $\mathrm{N}_{\mathrm{Li}_{2} \mathrm{O}}$ is the mole fraction of of $\mathrm{Li}_{2} \mathrm{O}$ in a saturated solution in lithium.

The solubilities calculated from Eq. 17 are considerably lower than those reported previously by Hoffman 46 and by Konovalov et al. 47 who used

similar experimental techniques but coarser filters (20 $\mu \mathrm{m}^{46}$ and $\left.30-40 \mu \mathrm{m}^{47}\right)$. Since undissolved $\mathrm{Li}_{2} \mathrm{O}$ may pass through coarse pore filters, 35 the lower solubility values reported in the ANL work are preferred over those of the earlier studies.

The solubllity of oxygen at the melting point of lithium (180.49 (') is $1.76 \times 10^{-4} \mathrm{~mol} \% \mathrm{Li}_{2} \mathrm{O}$ ( 4 wppm 0 ). This concentration defines a theoretical limit for oxygen removal from liquid 1 ithium that $c$ an be reached by coldtrapping in conjunction with the use of fine pore size $(<2 \mu \mathrm{m})$ filters.

\section{The Li-C System}

This system appears to have a single intermediate phase, $\mathrm{Li}_{2} \mathrm{C}_{2}$, which dissolves in lithium as an acetylide ion. Carbon added to lithium in any form will ultimately be converted to acetylide if heated to $600^{\circ} \mathrm{C} .48$

The solubility of acetylide in liquid lithium is being measured at ANL by Yonco et al. 49 by taking filtered samples (2- $\mu \mathrm{m}$ pore size filters) of saturated solutions of $\mathrm{Li}_{2} \mathrm{C}_{2}$ in $\mathrm{lithium}$ and analyzing for carbon by the acetylene-evolution method. 48 The data collected thus far vary between 
$9.0 \times 10^{-5} \mathrm{mo} 1 \% \mathrm{Li}_{2} \mathrm{C}_{2}$ at $200^{\circ} \mathrm{C}$ and $2.7 \times 10^{-2} \mathrm{~mol} \% \mathrm{Li}_{2} \mathrm{C}_{2}$ at $600^{\circ} \mathrm{C}$. The indicated solubility at the melting point of 1 ithium is $5 \times 10^{-5}$ mol $\% \mathrm{Li}_{2} \mathrm{C}_{2}$ (2 wppm $C$ ) which strongly implies that carbon elimination by cold-trapping methods should be feasible in liquid-lithium systems. Thermal analysis studies of Fedorov and Su50 yield acetylide solubilities that are at least ten times higher than those of Yonco et al. and are believed to be in error. 40 The available thermochemical data for $\mathrm{Li}_{2} \mathrm{C}_{2}$ have been summarized elsewhere. 37

Recently Down et al.51 reported the synthesis of dilithium cyanamide by reaction of lithium nitride with dilithium acetylide in excess lithium

$$
4 \mathrm{Li}_{3} \mathrm{~N}+\mathrm{Li}_{2} \mathrm{C}_{2} \rightarrow 2 \mathrm{Li}_{2} \mathrm{NCN}+10 \mathrm{Li}
$$

This is the first observation of a complex salt whose stability in liquid lithium is greater than that of the binary reactants; this information could contribute significantly to an understanding of lithium corrosion phenomena and nitrogen/carbon chemistry in liquid lithium.

\section{THERMODYNAMIC STUDIES RELATED TO SOLID BLANKETS}

The sorption characteristics of solid lithium-containing alloys toward the hydrogen isotopes constitute important considerations in evaluating the suitability of the alloys as fusion reactor blanket materials. There is very little information available on this subject in the literature. Early work, devoted mainly to the thermal decomposition of higher hydrides (e.g. $\mathrm{LiAlH}_{4} \mathrm{~S}^{2}$ ), has contributed little to the understanding of the dilute solutions of hydrogen in Li-M alloys. The dissolution of hydrogen in aluminum-rich solid Li-Al alloys has been analyzed by Owen and Randal1.53 The sorption of hydrogen in solid $\mathrm{Li}-\mathrm{Al}$ and $\mathrm{Li}-\mathrm{Pb}$ is currently under a thorough investigation at ANL using the hydrogen titration method (HTM). 54 The latter studies have shown that hydrogen sorption characterisitics in solid Li-M alloys can also be determined indirectly from the lithium activity data in binary Li-M alloys. Such data are available for a number of solid alloys from studies in which the traditional coulometric titration method (Cl'M) was employed.

\section{A. Hydrogen Titration Studies}

During the early stages of work at ANL it became apparent that lithiumbased alloys react with hydrogen in a different manner than do the alloys of the transition metals. Instead of forming stable ternary solutions, hydrogen reacts with the 1 ithium in the alloy to form solid $\mathrm{LiH}$, according to the following reversible reaction

$$
\mathrm{Li}(\text { in alloy })+1 / 2 \mathrm{H}_{2}(\mathrm{~g}) \neq \mathrm{LiH}(\mathrm{s})
$$

for which the equilibrium constant is given by

$$
K=a_{L i H} /\left(a_{L i} \sqrt{P}\right)
$$

where a is the activity of the subscripted component and $P$ is the equilibrium hydrogen pressure in atmospheres. 
According to Eq. 19, when small quantities of hydrogen are added to an alloy $\mathrm{LiM}_{\mathrm{X}}$, the composition of the alloy will change from $x=n_{M} / n_{L i}$ to a new composition $x=n_{M} /\left(n_{L} i-n_{H}\right)$. Equilibrium hydrogen pressures; measured after each consecutive hydrogen addition, produce isothermal $\sqrt{\mathrm{P}}$ vs. $x$ traces whose cascade-like shapes reflect the phase relationships in the binary Li-M systems--the homogeneous intermediate phases reveal themselves as rising segments and the two-phase coexistence fields appear as constant pressure plateaus. The process leading to the equilibrium in Eq. 19 is equivalent to a titration in which hydrogen is the titrant, LiH the titration product, and the equivalence points are identifiable from the shape of the isotherms. Hence, this method of investigating binary alloys is referred to as the hydrogen titration method (HTM).

Another important feature of HTM arises from the simple relationship between the measured decomposition pressures and the lithium activity in the binary Li-M alloy. Below the monotectic temperature of the Li-LiH system the LiH-rich phase is solid LiH. Therefore, the LiH precipitating out of LiM alloy may be taken to have unit activity and Eq. 20 becomes

$$
a_{\mathrm{Li}}=1 /(\mathrm{K} \sqrt{\mathrm{P}})
$$

The proportionality factor in Eq. 21 is the inverse of the equilibrium constant for the reaction in Eq. 19 which $c$ an be evaluated from the standard free energy of formation of solid LiH, given in Table 4. HTM thus provides a powerful new technique for investigating both the phase relationships and the lithium activities in Li-M alloys. The technique has been applied to two alloy systems: $\mathrm{Li}-\mathrm{Al}-\mathrm{H}$ and $\mathrm{Li}-\mathrm{Pb}-\mathrm{H} .54$

\section{The Li-Al-H System}

According to a recent phase diagram, 55 the Li-Al system has four homogeneous solid phases: $\alpha$ (dilute solution of lithium in aluminum), $\beta$ ("I,iAl"), $\gamma\left(" \mathrm{Li} \mathrm{Al}_{2}\right.$ "), and $\delta$ ("LigAl4"). The latter two phases are believed to be line compounds, but the highest melting $\beta$-phase has a wide homogeneity range (46-52 at. \% Al). Since the $\beta$-phase has been emphasized for fusion reactor applications, we have prepared two Li-Al alloys having compositions within this phase.

The resulte aro ohown in Fig. 5 as $10 \mathrm{~F}$ vs. al $\%$ Al isullerms. The fact that both alloys have produced essentially the same Al-rich 8 -phase boundary (about 52 at. \% Al) serves as a verification for the reaction in Eq. 19 . On the left side of this boundary the rising isothermal segments correspond to the homogeneity ranges of the $\beta$-phase. Constant pressure plateaus on the right side indicate the onset of a wide $(\alpha+\beta)$ two-phase region. Yao et al.56 have determined lithium activities from emf measurements on the 50 at. \% Al alloy at three temperatures $\left(314,343\right.$, and $\left.380^{\circ} \mathrm{C}\right)$. The corresponding hydrogen pressure values, extrapolated from their data to the temperatures of the HTM study, are in excellent agreement. Further agreement is indicated by comparisons in the $(\alpha+\beta)$ region, where the data produced by either technique are more reliable because of their insensitivity to variations in alloy composition. 


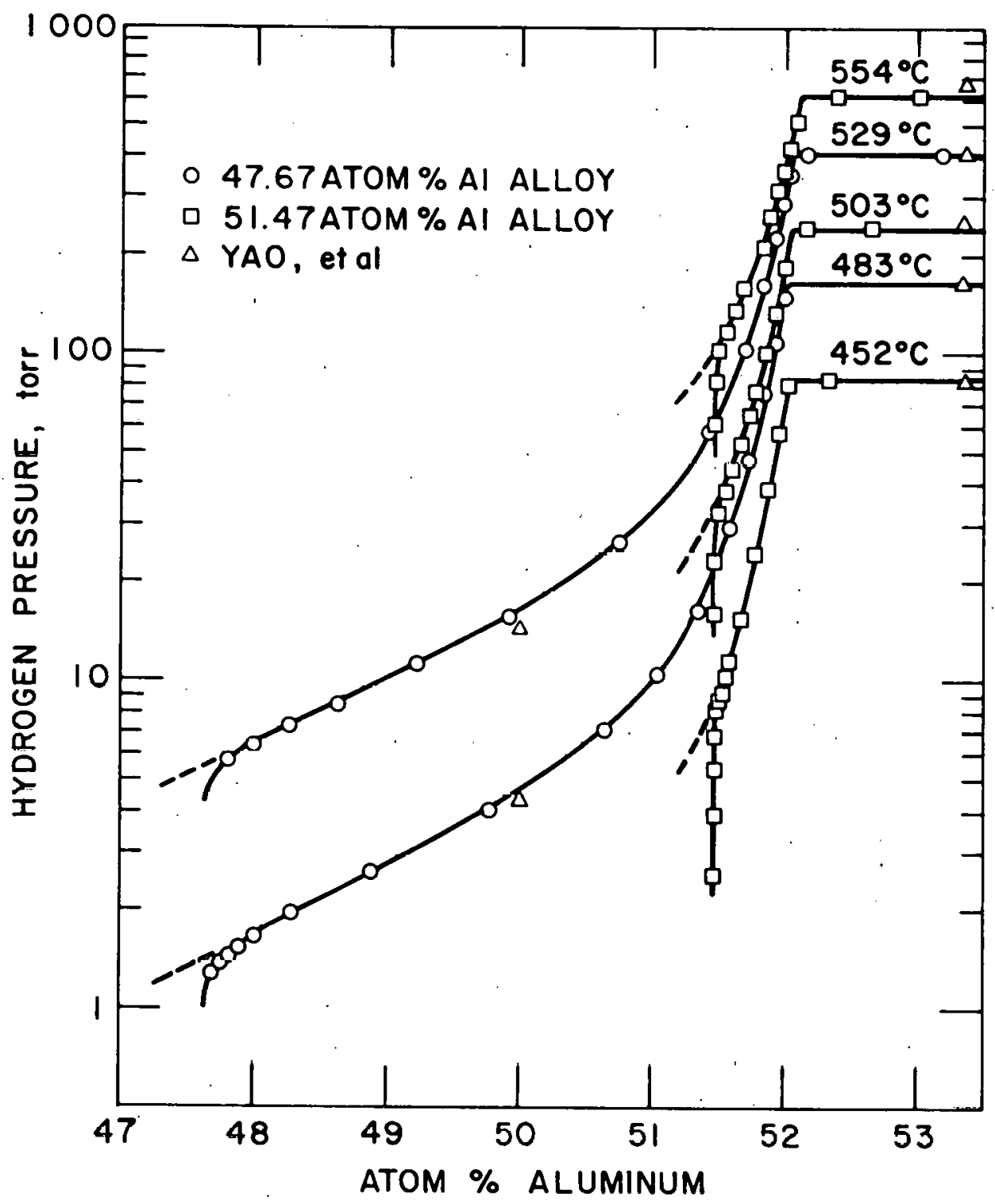

Fig. 5. Hydrogen Pressure vs. Alloy Composition Isotherms for the Li-Al System.

\section{The $\mathrm{Li}-\mathrm{Pb}-\mathrm{H}$ System}

The reliability of HTM is also being tested on the more complex Li-Pb alloy system. the reported phase diagram57 reveals several intermediate phases: $\mathrm{Li}_{22} \mathrm{~Pb}_{5}, \mathrm{Li}_{7} \mathrm{~Pb}_{2}, \mathrm{Li}_{3} \mathrm{~Pb}, \mathrm{Li} 8 \mathrm{~Pb}_{3}$, and $\mathrm{LiPb}$. HTM results are shown in Fig. 6. Three of the isotherms (at 500, 549, and $598^{\circ} \mathrm{C}$ ) were obtained with an alloy having an initial $\mathrm{Pb} / \mathrm{Li}$ ratio of 0.2610 . The fourth isotherm (also at $500^{\circ} \mathrm{C}$ ) had an initial $\mathrm{Pb} / \mathrm{Li}$ ratio of 0.2858 . 


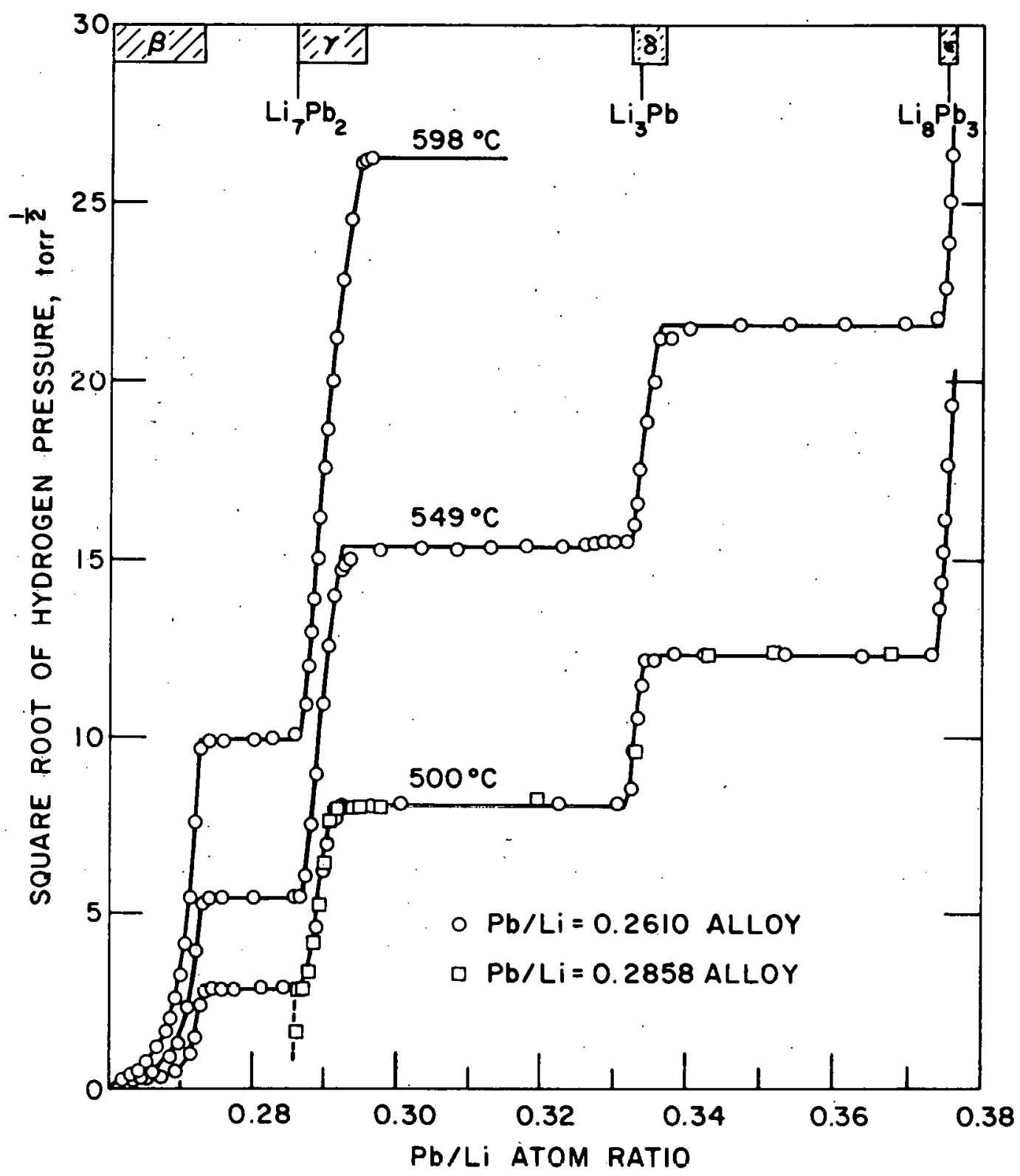

Fig. 6. Square Root of Hydrogen Pressure vs. Al loy Composition Isotherms for the Li-Pb System.

The isotherms have the expected cascade-like shapes with four rising portions separated by three pressure plateaus. Each of the rising portions was assigned $a$ band $(\beta, \gamma, \delta$, and $\varepsilon$ ) representing the maximum limits of homogeneity for that phase. The bands $\gamma, \delta$, and $\varepsilon$ include the stoichiometries of the phases $\mathrm{Li}_{7} \mathrm{~Pb}_{2}, \mathrm{Li}_{3} \mathrm{~Pb}$, and $\mathrm{Li}_{8} \mathrm{~Pb}_{3}$, respectively. For concentrations below $\mathrm{Pb} / \mathrm{Li}=2 / 7$, the shape of the isotherms suggest the existence of a wide homogeneous phase $(B)$, whose lead-rich boundary may correspond to $\mathrm{Li}_{11} \mathrm{~Pb}_{3}$. 
Lithium activities, calculated for each two-phase plateau portion from the corresponding hydrogen pressure using Eq. 21 show an excellent agreement with those recently determined by the coulometric titration technique. 58 This agreement and the superimposition of the two isotherms at $500^{\circ} \mathrm{C}$ in $\mathrm{Fig} .6$, despite their different starting compositions, lends further credence to the applicability of HTM in investigating the thermodynamic properties and phase relations of binary lithium-containing alloys.

\section{B. Coulometric Titration Studies}

According to Eq. 21 , if isothermal a $a_{\mathrm{Li}}$ vs. C data were available for a Li-M alloy, one could construct a corresponding set of $\sqrt{\mathrm{P}}$ vs. C i sotherms that represent hydrogen sorption characteristics of that alloy. Electromotive force measurements provide a convenient means of determining activities in binary alloys. For Li-M systems these measurements $c$ an be carried out in cells of the type [Li(l)/Li-salt/Li-M(alloy)] in which the isothermal rell pmfs arp continuously recorded as functions of the alloy concentration which is varied by the coulometric titration method (CTM).

CTM studies on the $\mathrm{Li}-\mathrm{Al} 56,59$ and $\mathrm{Li}-\mathrm{Pb} 58$ systems and their agreement with the HTM data were mentioned above: Other solid alloy systems, for which CTM data are available, are: Li-Bi, $60 \mathrm{Li}-\mathrm{Sb}, 60$ and Li-Si.61,62 Lithium activities and the corresponding hydrogen decomposition pressures, calculated using data of these studies at $500^{\circ} \mathrm{C}$, are given in Table 5 for selected intermetallic compounds, that show promise in fusion reactor applications.

Table 5. Maximum Hydrogen Pressures (or minimum lithium activities) at $500^{\circ} \mathrm{C}$ that can be Reached in solutions of Hydrogen in Selected Intermetallic Compounds Containing Litlıium.

\begin{tabular}{lccc}
\hline Cumpound & $\begin{array}{c}\mathrm{mp}, \\
{ }^{\circ} \mathrm{C}\end{array}$ & $\mathrm{a}_{\mathrm{Li}}$ & $\begin{array}{c}\mathrm{P}_{\max }, \\
\text { atm }\end{array}$ \\
\hline $\mathrm{Li}_{3} \mathrm{Sb}$ & $\sim 1200$ & $2.5 \times 10^{-6}$ & $1.0 \times 10^{7}$ \\
$\mathrm{~L}_{3}{ }_{3 \mathrm{Bi}}$ & 1145 & $2.5 \times 10^{-3}$ & $1.1 \times 10^{\mathrm{b}}$ \\
$\mathrm{Li}_{8} \mathrm{~Pb}_{3}$ & $642^{\mathrm{b}}$ & $4.8 \times 10^{-3}$ & 3.0 \\
$\mathrm{Li}_{3} \mathrm{~Pb}$ & $658^{\mathrm{b}}$ & $2.0 \times 10^{-2}$ & $1.6 \times 10^{-1}$ \\
$\mathrm{Li}_{7} \mathrm{~Pb} 2$ & 726 & $3.2 \times 10^{-2}$ & $6.8 \times 10^{-2}$ \\
$\mathrm{~B}-\mathrm{LiAl} \mathrm{a}$ & 700 & $7.5 \times 10^{-2}$ & $1.2 \times 10^{-2}$ \\
$\mathrm{Li}_{2} \mathrm{Si}$ & 703 & $1.7 \times 10^{-2}$ & $2.4 \times 10^{-1}$ \\
$\mathrm{Li}_{4} \mathrm{Si}$ & $635^{\mathrm{b}}$ & $5.9 \times 10^{-1}$ & $1.9 \times 10^{-4}$ \\
$\mathrm{Li}$ thium & $1 \mathrm{qquid}$ & 1.0 & $5.0 \times 10^{-1} 0^{\mathrm{c}}$ \\
\hline
\end{tabular}

\footnotetext{
${ }^{a}$ At 50 at. \% Al.

Incongruent melting.

${ }^{c}$ At $\mathrm{N}_{\mathrm{H}}=10^{-4}$.
} 


\section{Solubility of Hydrogen in Solid Lithium Alloys}

The slight inclination in the initial vertical portions of the isotherms in Fig. 5 implies that there is some dissolution of hydrogen in Li-M alloys. Only when the hydrogen solubility limit is exceeded, can the precipitation of LiH occur, according to Eq. 19. This information is important in fusion reactor applications because it relates to the concentration of tritium present in the blanket medium under steady-state operating conditions.

Very little information is available on these solutions. Talbot et al. have determined the Sieverts' law constants $\left(K_{S}=N_{H} / \sqrt{P}\right)$ for tritium in LiAl and $\mathrm{LiBi} 5.6$ al loys 63 and for hydrogen in LiAl alloy.64 Current work at ANL on the dissolution of hydrogen in $\mathrm{Li}-\mathrm{Al}$ and $\mathrm{Li}-\mathrm{Pb}$ alloys, 54 however, indicates considerably lower $\mathrm{K}_{\mathrm{S}}$ values.

Lacking exact hydrogen solubility data, one can at tempt to estimate the magnitude of $\mathrm{K}_{\mathrm{S}}$ from CTM data, such as those listed in. Table 5 . The estimates are made by assuming that the same hydrogen solubility limit (e.g., $\mathrm{N}_{\mathrm{H}}=10^{-4}$ ) exists for all alloys and that Sieverts' law is obeyed throughout the solution range, i.e., $\mathrm{K}_{\mathrm{S}} \propto 1 / \sqrt{\mathrm{P}_{\max }}$.

Materials possessing large $P_{\max }$ values are more desirable for blanket applications because of the increased tendency of hydrogen isotopes to favor the gas phase, thereby facilitating tritium removal and reducing tritium inventory in the condensed blanket phase. The compounds listed in Table 5 show large variations in $P_{\max }$ which could be useful as a criterion in selecting an appropriate alloy. In all cases the $P_{\max }$ values are much 1 arger than the equivalent value for liquid lithium, which is also shown in Table 5 for comparison.

\section{STUDIES RELATED TO CERAMIC BLANKETS}

There is little thermodynamic information that pertains to the use of ceramics as breeder blanket materials. This section will be devoted to a brief discussion of available literature studies on the lithium-containing ceramics, 7,8,10,53,65 which describe the kinetics of tritium extraction from these materials. In these studies tritium is introduced into the ceramic specimens by neutron irradiation via the $\left(n, 6_{L i}\right)$ and $\left(n, 7_{L i}\right)$ transmutations. Since this procedure is analogous to the mode of tritium production in fusion reactor blankets, the experience gained should readily extrapolate to fusion reactor operating conditions.

Powell et al. 7 and Wiswall and Wirsing 8 have reported that temperatures in excess of $600^{\circ} \mathrm{C}$ were necessary to recover $>99 \%$ of the tritium from $\mathrm{Li}_{2} \mathrm{O}$, $\mathrm{LiAlO}_{2}$, and $\mathrm{Li}_{2} \mathrm{SiO}_{3}$ granules in one hour or less. Johnson et al. 10 have observed that, during the neutron irradiation itself, $>80 \%$ of helium and from 9 to $90 \%$ of tritium was released from the ceramic targets, the amount of tritium released being inversely proportional to the bulk density of the target material. The tritium appeared mostly in a noncondensible form (HT or $\mathrm{T}_{2}$ ) but 
the fraction of the condensible form (HTO or $\mathrm{T}_{2} \mathrm{O}$ ) increased with increasing temperature of the target. Release of tritium from $\mathrm{LiAlO}_{2}$ targets was also investigated by Yunker.65 His data have shown that essentially all of the tritium can be recovered by vacuum outgassing at $850^{\circ} \mathrm{C}$ with a large fraction of tritium appearing in a condensible form.

It can be concluded from the results of these studies that thermal extraction can be an effective method of removing tritium from the oxide-type ceramics. A small fraction of tritium bred in a ceramic blanket will be ejected in situ into the gas space by direct recoil. The remaining tritium will diffuse to the surface of the hot ceramic granules where it $c$ an be swept away by a purge gas. Lower tritium inventory in the blanket can be effected by increasing its steady-state operating temperature and/or by decreasing the mean size of the granules.

\section{RECOMMENDATIONS FOR FUTURE RESEARCH}

The impetus of the fusion energy program has already stimulated a significant amount of thermodynamic research on the candidate blanket materials. Nevertheless, more work is required for full evaluation of the in-reactor performance of these materials. In this section we will attempt to point out some areas where thermodynamic data are either lacking or are in need of verification.

As was shown above, the existing thermodynamic data on lithium are quite substantive. There still are, however, areas where additional information would be beneficial. The uncertainty remaining in the Sieverts' law constants for tritium would be:clarified by additional experiments on very dilute solutions of tritium in lithium. The stability and precipitation of oxide species in liquid lithium and conditions for their removal by cold-trapping need further investigation. Identification and characterization of the carbon/nitrogen species formed in dilute solutions in lithium should be undertaken. Correlation of these latter studies with lithium corrosion data could provide a clearer understanding of the compatibility of lithium with structural materials.

Considerably more work is needed to complete the thermodynamic data base for solid lithium alloy systems. Accurate measurements of Sieverts' law constants for tritium in these alloys would provide a firmer basis for evaluating blanket inventories. Thermodynamic properties of the systems formed between the alloys and non-metallic impurity elements may be important in determining long-term tritium release characteristics. Thermochemical data for many of the candidate alloys are needed in evaluating thermal hydraulic response, safety aspects related to accidental melt-down, and possible uses as thermal storage sinks to sustain pulsed thermonuclear power production. Pressure-composition-temperature data on solutions of hydrogen isotopes in the alloys that are on the lithium-rich ends of the corresponding phase diagrams would contribute insight on the potential utility of "slightlyalloyed" liquid lithium as a blanket material.

From the standpoint of thermodynamic data, ceramics are the least-studied category of the blanket materials. There are essentially no data available on the sorption of hydrogen isotopes in the prospective ceramic materials 
under anticipated fusion reactor operating conditions. The effects of impurity elements on the performance of these materials need to be investigated. Thermochemical and sintering information are also needed for the same reasons as were mentioned in the preceding paragraph for the solid lithium alloys.

\section{ACKNOWLEDGMENTS}

The work originating at the Argonne National Laboratory was supported by the Division of Basic Energy Sciences, U.S. Department of Energy. The interest and encouragement of R. P. Epple, F. A. Cafasso, and L. Burris, Jr. are gratefully acknowlcdgcd. 
REFERENCES

1. F. L. Ribe, Rev. Mod. Phys. 47,7 (1975).

2. T. B. Rhinehammer and L. J. Wittenberg, An Evaluation of Fuel Resources and Requirements for the Magnetic Fusion Program, Mound Laboratory, Monsanto Research Corporation, Report MLM-2419 (1978).

3. Proc. Magnetic Fusion Energy Blanket and Shield Workshop, J. R. Powe11, J. A. Fillo, B. G. Twining, and J. J. Dorning, Eds., U. S. Dept. of Energy Report CONF-760343 (1975).

4. Proc. 2nd Topical Meeting, on Technology of CTR, J. L. Kulcinski, Ed., U.S. Dept. of Energy Report CONF-760935 (1976).

5. Proc. 7th Symp. on Engineering Problems of Fusion Research, M. S. Lubell and C. Whitmore, Edo., IEEE Publioation No. 77CH1267-4-NPS (1977).

6. G. A. Carlson, Magnetohydrodynamic Pressure Drop in Lithium Flowing in Conducting Wall Pipe in a Transverse Magnetic Field--Theory and Experiment, Lawrence Livermore Laboratory Report UCRL-75307 (1974).

7. J. R. Powe11, R. H. Wiswall, and E. Wirsing, Tritium Recovery from Fusion Blankets Using Solid Lithium Compounds, Brookhaven National Laboratory Report BNL-20563 (1975).

8. R. H. Wiswall and E. Wirsing, The Removal of Tritium from Fusion Reactor Blankets, Brookhaven National Laboratory Report BNL-50748 (1977).

9. D. K. Sze and D, C, Sçhluderberg, Trans. Am. Nucl. Soc. 30, 68 (1978).

10. A. B. Johnson, T. J. Kabele, and W. E. Gurwe11, Tritium Production from Ceramic Targets: A Summary of the Hanford Coproduct Program, Battelle Pacific Northwest. Laboracorfes Report BNWL-2097 (1976).

11. C. E. Messer, A Survey Report on Lithium Hydride, AEC Research and Development Report NYO-9470(1960).

12. E. E. Shpilrain and K. A. Yakimovich, Lithium Hydride. Physicochemical and l'hermophysical properties, state sèrivice of Standard and Reference Data. Monograph Series No. 10, Moscow (1972).

13. C. B. Magee, Metal Hydrides, W. M. Mueller, J. P. Blackledge, and

G. G. Libowitz, Eds., Academic Press, New York, Chapt. 6 (1968).

14. E. Veleckis, E. H. Van Deventer, and M. Blander, J. Phys. Chem. 78, 1933 (1974).

15. E. Veleckis, J. Phys. Chem. 81, 526 (1977).

16. J. H. Hildebrand and R. L. Scott, The Solubility of Nonelectrolytes, 3rd Ed., Reinhold, New York, p.34 (1950). 
17. E. Veleckis, R. M. Yonco, and V. A. Maroni, J. Less-Common Met. 55, 85 (1977.).

18. F. J. Smith, A. M. Batistoni, G. M. Begun, and J. F. Land, (a) Proc. 9th Symp. Fusion Technology, Pergamon Press, New York, 325 (1976); (b) submitted for publication in J. Inorg. Nuc1. Chem.

19. F. J. Smith, J. D. Redman, R. A. Strehlow, and J. T. Bell, Proc. Symp. Tritium Technology Related to Fusion Reactor Systems, W. H. Smith, W. R. Wilkes, and L. J. Wittenberg, Eds., ERDA-50, p. 41 (1975).

20. G. M. McCracken, D. H. J. Goodall, and G. Long, The Extraction of Tritiumm from Liquid Lithium, IAEA Workshop on Fusion Reactor Design Problems, Culh am, U. K. (1974).

21. H. R. Ihle and C. H. Wu, Proc. 8th Symp. on Fusion Technology, Noordwijkerhout, The Netherlands, EUR-5182C, p. 787 (1974)

22. P. F. Adams, M. G. Down, P: Hubberstey, and R. J. Pulham, J. Less-Common Met. $\underline{42}, 325$ (1975).

23. P. F. Adams, P. Hubberstey, R. J. Pulham, and A. E. Thunder, J. Less-Common Met: 46, 285 (1976).

24. G. N. Lewis and M. Randal1, Thermodynamics, revised by K.S. Pitzer and L. Brewer, 2nd Ed., McGraw-Hill, New. York, p. 404 (1961).

25. E. E. Shpilrain, K. A. Yakimovich, D. N. Kagan, and V. G. Shvalb, Fluid Mech.-Sov. Res. 3 , 3 (1974).

26. F. J. Smith and J. F. Land, Trans. Am. Nucl. Soc., Annual Meeting, p. 167 (1975).

27. E. E. Shpilrain, K. A. Yakimovich, and V. A. Shereshevskii, Teplofiz. Vys. Temp. 15, 661 (1977).

28. H. R. Ihle and C. H. Wu, J. Inorg. Nucl. Chem. 36, 2167 (1974).

29. H. Katsuta, T. Ishigai, and K. Furukawa, Nuc1. Technol. 32, 297 (1977).

30. H. M. Smith and R. E. Webb, Equilibrium Dissociation Pressures of Lithium Hydride and Lithium Deuteride, Oak Ridge V-12 Plant, Oak Ridge, TN, Y-2095 (1977).

31. E. Veleckis, I. Nuc1. Mater. 79, 20 (1979).

32. H. R. Ihle and C. H. Wu, Proc. 2nd Int. Congress on Hydrogen in Metals, Pergamon Press, New York, paper 1D8 (1977).

33. H. R. Ihle and C. H. Wu, J. Phys. Chem. 79, 2386 (1975).

34. C. E. Messer, The Alkali Metals, The Chem. Soc. (London) Spec. Bull. No. 22 , p. 183, (1966). 
35. E. J. Cairns, F. A. Cafasso, and V. A. Maroni, The Chemistry of Fusion Technology, D. M. Gruen, Ed., Plenum Press, New York, pp. 91-160 (1972).

36. P. F. Adams, P. Hubberstey, and R. J. Pulham, J. Less-Common Met. 42,1 (1975).

37. J. F. Smith and Z. Moser, J. Nucl. Mater. 59, 158 (1976).

38. K. A. Bolshakov, P. I. Fedorov, and F. A. Stepina, Izv. Vyssh. Uchebn. Zaved. Tsvetn. Metall. $\underline{2}, 52$ (1959).

39. R. M. Yonco, E. Veleckis, and V. A. Maroni, J. Nucl. Mater. 57, 317 (1975).

40. P. Hubberstey, R. J. Pulham, and A. E. Thunder, J. Chem. Soc., Faraday Trans. 1,431 (1976).

41. JANAF Thermochemical Tables, Dow Chemical Co., Midland, MI (March 31, 1978).

42. P. A. G. O'Härè and G. K. Johnson, J. Chem Thermodyn. 7, 13 (1975).

43. D. W. Osborne and H. E. Flotow, J. Chem. Thermodyn. 10, 675 (1978).

44. A. Bonomi, M. lladate, and C. Gentaz, Proc. Int. Symp. on Molten Salts, J. P. Pemsler, J. Braunstein, D. R. Morris, K. Nobe, and N. E. Richards, Eds., The Electrochemical Society, Princeton, NJ, 1976, p. 78.

45. R. M. Yonco, V. A. Maroni, J. E. Strain, and J. H. DeVan, J. Nucl. Mater. 79, 354 (1979).

46. E. E. Hoffman, Newer Metals, Am. Soc. Test. Mater., Spec. Tech. Pub1. 272 , p. $195(1960)$.

4\%. E. E. Konovalov, N. E. Seliverstov, and V. P. Emelyanov, Russ. Metall. $\underline{3}$, 77 (1969).

48. E. M. Hobart and R. G. Bjork, Anal. Chem. 39, 202 (1967).

49. R. M. Yonco and M. I. Homa, accepted for presentation at the ANS Annual Meeting, Atlanta, GA, June 3-7, 1979.

50. P. I. Fedorov and M. T. Su, Acta Chim. Sinica 23, 30 (1957).

51. M. G. Down, M. J. Haley, P. Hubberstey, R. J. Pulham, and A. E. Thunder J. Chem. Soc. Chem. Comm., 52 (1978).

52. S. Aronson and F. J. Salzano, Inorg. Chem. $\underline{8}, 1541$ (1969).

53. J. H. Owen and D. Randal1, Proc. Int. Conf. on Radiation Effects and Tritium Technology for Fusion Reactors, J. S. Watson and F. W. Wiffen, Eds., Rep. CONF-750989 (1976), III-433.

54. E. Veleckis, Argonne National Laboratory, work in progress. 
55. K. M. Myles, F. C. Mrazek, J. A. Smaga, and J. C. Settle, Proc. Symp. and Workshop on Advanced Battery Research and Design, Argonne National Laboratory Report ANL-76-8, 50B (1976).

56. N. P. Yao, L. A. Heredy, and R. C. Saunders, J. Electrochem. Soc. 118 , $1039(1971)$.

57. R. Hultgren, P. D. Desai, D. T. Hawkins, M. Gleiser, and K. K. Kelley, Selected Values of the Thermodynamic Properties of Binary Alloys, Am. Soc. Metals; Metals Park, OH, p. 1078 (1973).

58. M. L. Saboungi and J. Marr, Argonne National Laboratory, personal communication.

59. C. J. Wen, B. A. Baukamp, and R. A. Huggins, Extended Abstracts, The Electrochem. Soc. 78-1, Abstract No. 171 (1978).

60. W. Weppner and R. A. Huggins, J. Electrochem. Soc. 125, 7 (1978).

61. R. A. Sharma and R. N. Seeforth, J. Electrochem. Soc. 123, 1763 (1976).

62. S. Lai and.L. R. McCoy, Extended Abstracts, The Electrochem. Soc., 75-2, Abstract No. 21 (1975).

63. J. B. Talbot, A Study of Tritium Removal from Fusion Reactor Blankets of Molten Salt and Lithium-Aluminium, Oak Ridge National Laboratory Report ORNL/TM-5104 (1976).

64. J. B. Talbot, F. J. Smith, J. F. Land, and P. Barton, J. Less-Common Met. 50, 23 (1976).

65. W. Yunker, Extraction of Tritium from Lithium Aluminate, Hanford Engineering Development Laboracory Repore HËL̃L-TME 76-81 (1976). 


\section{Internal:}
L. Burris
W. F. Calaway
F. A. Cafasso
R. G. Clemmer
C. C. Baker
N. R. Chellew
S. D. Harkness
L. R. Greenwood
D. L. Smith
J. R. Weston
B. M. Abraham
E. H. Van Deventer

R. M. Yonco (5)

V. A. Maroni (5)

E. Veleckis (5)

A. B. Krisciunas

ANL Contract File

ANL Libraries (5)

T. F. Kassner

TIS Files (6)

\section{External:}

DOE-TIC, for distribution per UC-20c (202)

Manager, Chicago Operations and Regional Office, DOE

Chief, Utfice of Patent Counsel, DOE-CORO

President, Argonne Universities Association

Chemical Engineering Division Review Committee:

C. B. Alcock, U. Toronto

R. C. Axtmann, Princcton II.

R. E. Balzhiser, Electric Power Research Inst.

J. T. Banchero, U. Notre Dame

T. Cole, Ford Motor Co.

P. W. Gilles, U. Kansas

R. I. Newman, Allied Chemical Corp.

G. M. Rosenblatt, Pennsylvania State U.

J. L. Anderson, Los Alamos Scientific Lab.

J. E. Baublitz, Office of Fusion Energy, USDOE

J. T. Bell, Oak Ridge National Lab.

D. Carstens, Los Alamos Scientific Lab.

F. E. Coffman, Office of Fusion Energy, USDOE

J. H. DeVan, Oak Ridge National Lab.

R. P. Epple, Div. Basic Energy Sciences, USDOE

C. R. Head, Office of Fusion Energy, USDOE

R. G. Hickman, Lawrence Livermore Lab.

E. K. Hulet, Lawrence Livermore Lab.

G. G. Libowitz, Allied Chemical Corp., Morristown, N.J.

G. R. Nardella, Office of Fusion Energy, USDOE

J. R. Powell, Brookhaven National Lab.

T. C. Reuter, Jr., Office of Fusion Energy, USDOE

F. J. Smith, Oak Ridge National Lab.

H. M. Smith, Oak Ridge National Lab.

J. F. Smith, Ames Lab.

D. K. Stevens, Div. Basic Energy Sciences, USDOE

J. S. Watson, Oak Ridge National Lab.

W. R. Wilkes, Mound Lab.

R. H. Wiswall, Brookhaven National Lab.

M. C. Wittels, Div. Basic Energy Sciences, USDOE

J. T. Wittenberg, Mound Lab.

K. M. Zwilsky, Office of Fusion Energy, USDOE

P. F. Adams, U. Nottingham, Great Britain

K. Furukawa, Japan Atomic Energy Research Inst.

D. H. J. Goodall, Culham Lab., Great Britain

H. Katsuta, Japan Atomic Energy Research Inst.

R. J. Pulham, U. Nottingham, Great Britain

E. E. Shpilrain, Inst. High Temperatures, Moscow

K. A. Yakimovich, Inst. High Temperatures, Moscow 